EFFECTS OF THE 1980 ERUPTION OF MOUNT ST. HELENS ON THE LIMNOLOGICAL CHARACTERISTICS OF

SELECTED LAKES IN WESTERN WASHINGTON

By S. S. Embrey and N. P. Dion

U. S. GEOLOGICAL SURVEY

Water-Resources Investigations Report 87-4263

Tacoma, Washington

1988 
DEPARTMENT OF THE INTERIOR

DONALD PAUL HODEL, Secretary

U. S. GEOLOGICAL SURVEY

Dallas L. Peck, Director

For additional information

write to:

District Chief

U.S. Geological Survey

1201 Pacific Ave., Suite 600

Tacoma, Washington 98402-4384
Copies of this report can be purchased from:

U. S. Geological Survey Books and Open-File Reports Federal Center, box 25425

Denver, Colorado 80225 
Abstract-

Introduction--

Methods of data collection and analysis

Major effects on existing study lakes in western Washington,

May 1980 to October $1980 \ldots$

Posteruption, physical, chemical, and biological conditions

in existing and newly created study lakes in western

Washington, June 1980 to August 1982

Physical characteristics- $\ldots \ldots \ldots \ldots$

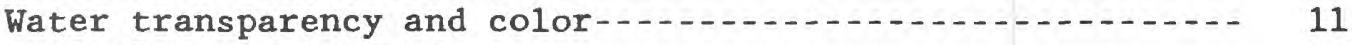

Chemical characteristics- 16

Dissolved oxygen-........ 16

Inorganic and organic chemistry 19

Biological characteristics . . . . . . .

Chlorophy11_......... 24

Phytoplankton-_....... 26

Zooplankton-........... 33

Higher organisms -

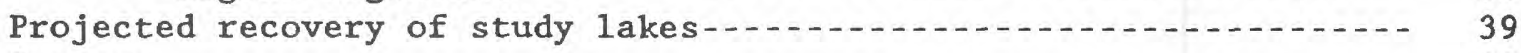

Summary-............

References cited-_.

Appendices

A. Taxonomic identification of phytoplankton in eight study lakes in the Mount St. Helens area, Washington_....... 46

B. Taxonomic identification of zooplankton in eight study lakes in the Mount St. Helens area, Washington-....... 
FIGURE 1, Map showing location of the study area and study

lakes affected by the May 18, 1980, eruption of

Mount St. Helens, Washington-.... 4

2. Cross-sectional sketch and map showing change in

Spirit Lake before and after the May 18, 1980,

eruption of Mount St. Helens, Washington-......- 8

3-4. Bathymetric map, after May 18, 1980, of:

3. St. Helens Lake-... 9

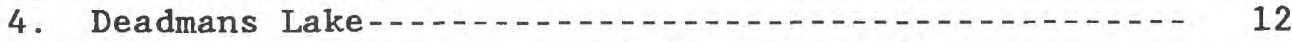

5-6. Bathymetric map, after construction of outflow

channels of:

5. Coldwater Lake-..... 13

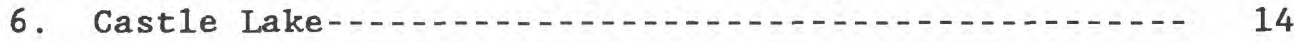

7-14. Graphs showing:

7. Water transparency, from Secchi-disc measurements

in study lakes near Mount St. Helens,

Washington, June 1980 to August 1982_....... 15

8. Selected dissolved-oxygen profiles of study

lakes before and after the May 18, 1980 ,

eruption of Mount St. Helens, Washington-.....-

9. Major-ion concentrations in selected study

lakes lying directly north of the volcano

in the line of the eruption blast zone near

Mount St. Helens, Washington-....

10. Chlorophyl1 a concentrations in the study

lakes near Mount St. Helens, Washington,

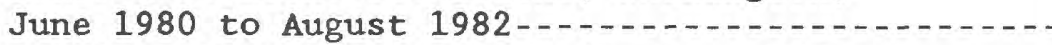

11. Phytoplankton concentrations in the study lakes near Mount St. Helens, Washington, June 1980 to August 1982.......

12. Percentage composition of phytoplankton communities in the study lakes near Mount St.

Helens, Washington, June 1980 to August 1982-...-

13. Zooplankton concentrations in the study lakes near Mount St. Helens, Washington, June 1980 to August 1982....

14. Percentage composition of zooplankton communities in the study lakes near Mount St. Helens, Washington, June 1980 to August 1982....- 
TABLE 1. Periods of data collection and physical features of

11 study lakes affected by the eruption of

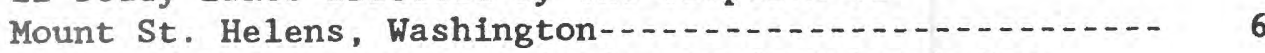

2. Quality of water in four existing study lakes before and immediately after the May 18, 1980, eruption

of Mount St. Helens, Washington-........ 10

3. Quality of water in six study lakes near Mount

St. Helens, Washington, in 1981 and 1982 22

4. Water types in eight study lakes before and after

the May 18, 1980, eruption of Mount St. Helens,

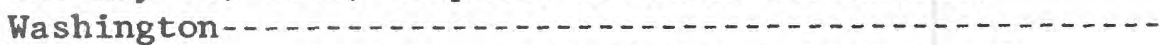

5. Average summer concentrations of chlorophyll a and

average percentages of pheophytin a during summer

1981 and summer 1982 in six study lakes near Mount

St. Helens, Washington-..... 26

6. Shannon diversity indices and evenness for phytoplankton communities in eight study lakes near

Mount St. Helens, Washington, 1980 to $1982 \ldots \ldots . . . .$.

\section{CONVERSION FACTORS}

For the convenience of readers who may prefer to use metric (International System) units rather than the inch-pound units used in this report, values may be converted by using the following factors:

Multiply inch-pound units

by to obtain metric units

inch (in.)

foot $(\mathrm{ft})$

mile (mi)

acre

acre-foot (ac-ft)

25.4
0.3048
1.609
4,047
1,233

millimeter (mm)

meter (m)

kilometer $(\mathrm{km})$,

square meter $\left(m^{2}\right)$

cubic meter $\left(\mathrm{m}^{3}\right)$

Sea leve1: In this report "sea level" refers to the National Geodetic Vertical Datum of 1929 (NGVD of 1929)--a geodetic datum derived from a general adjustment of the first-order level nets of both the United States and Canada, formerly called "Mean Sea Level of 1929."

degree Fahrenheit $\left({ }^{\circ} \mathrm{F}\right)$ to degree Celsius $\left({ }^{\circ} \mathrm{C}\right):{ }^{\circ} \mathrm{C}=5 / 9\left({ }^{\circ} \mathrm{F}-32\right)$ 
EFFECTS OF THE 1980 ERUPTION OF MOUNT ST. HELENS ON THE LIMNOLOGICAL CHARACTERISTICS OF SELECTED LAKES IN WESTERN WASHINGTON

By S. S. Embrey and N. P. Dion

\section{ABSTRACT}

The 1980 eruption of Mount St. Helens, Washington, afforded an opportunity to study its physical, chemical, and biological effects on lakes near the volcano and to describe two newly created lakes. From June 1980 to August 1982, water samples were collected from four lakes in the blast zone and two outside the blast zone, as well as from the two newly created lakes. Concentrations of chemical constituents were inversely related to the distance of a lake from the volcano. Dissolved solids and total organic carbon, measured in June 1980, had increased from 2 to 30 times the concentrations observed in the 1970's in Spirit, St. Helens, and Venus Lakes. Major-ion composition and the water types of the study lakes except Walupt Lake were altered from preeruption calcium-bicarbonate types to calcium-sulfate, calcium-sulfate-chloride, or mixed types.

St. Helens Lake had the shallowest Secchi-disc depth transparency of all the study lakes ( 6 inches) and showed the least improvement by 1982 . Water transparency in Venus Lake had improved to a depth of 24 feet by 1982 . Although Spirit Lake had been heated to more than 32 degrees Celsius during the eruption, the water surface had cooled to near preeruption levels (13 degrees celsius) by October 1980. Spirit Lake was anoxic through fall 1980 , but by May 1981 dissolved-oxygen concentrations had become 5.2 and 3.2 milligrams per liter near the surface and the bottom, respectively.

Phytoplankton communities in existing lakes in the blast zone in 1980 were primarily green and bluegreen algae; diatoms were relatively sparse in the blast-zone lakes until summer 1982. Smaller numbers of zooplankton in Spirit, St. Helens, and Venus Lakes, compared with Walupt and Fawn Lakes, may indicate some posteruption mortality. Rotifers, which dominated the zooplankton community of Deadmans Lake, were absent from lakes in the blast zone in 1980, but by 1981 were observed in all the lakes.

The recovery of physical, chemical, and biological characteristics of the lakes will depend on stabilization of the volcano and lake watersheds, dilution and water-exchange rates, and biological processes within each lake. Excluding Spirit Lake from consideration, it was estimated from the study that St. Helens Lake would be the slowest of the study lakes to recover, and Venus Lake would be the fastest. 


\section{INTRODUCTION}

The major eruption of Mount St. Helens, Washington, on May 18, 1980, deposited tons of ash, mud, logs, and other debris into more than 30 nearpristine lakes in the immediate vicinity of the volcano. Even lakes in parts of eastern Washington received deposits of windblown ash as much as 3 inches thick (Sarna-Wojcicki and others, 1980). The blast zone is defined in this report as the area immediately northwest, north, and northeast of the volcano that was affected by the violent explosion, or blast, that marked the beginning of the May 18, 1980, eruption (see fig. 1). A detalled chronology of conditions immediately preceding and following the eruption is provided by Foxworthy and Hill (1982).

This event provided a unique opportunity to describe the posteruption physical, chemical, and biological characteristics in affected lakes. One or more of the following criteria were used to select eight lakes for study: (1) the lake received ash deposits from the May 18 eruption; (2) background data were available from previous studies by the U. S. Geological Survey for comparison with current data; and (3) lakes in the immediate vicinity of the volcano were sufficiently close to be affected by deposits of pyroclastic material, ash, ice, mud, or timber. Data collection began in June 1980 at the following study lakes: Spirit, St. Helens, Venus, Fawn, and Walupt Lakes in western Washington, and Warden, Sprague, and Amber Lakes in eastern Washington (fig. 1). Data collection on Fawn, Walupt, Warden, Sprague, and Amber Lakes ended in October 1980 and on Spirit, St. Helens, and Venus Lakes in August 1982 .

Dion and Embrey (1981) summarized the results of the first 5 months of the investigation for the eight study lakes. Evaluation of the data in October 1980 indicated that the eruption did not have major, immediate effects on the study lakes in eastern Washington, nor on Walupt Lake in western Washington, compared to the degree of effect on Spirit, St. Helens, and Venus Lakes. At the same time, new lakes were forming in the valleys of streams that, prior to the eruption, were tributary to the North Fork Toutle River and were dammed by a 17-mile-long plug of debris deposited in the upper valley of Toutle River. The decision was made to discontinue data collection on the three eastern Washington lakes and to substitute for study, two newly created lakes in western Washington, Coldwater and Gastle Lakes. Walupt Lake was also dropped from the study and replaced by Deadmans Lake.

The purpose of the investigation was to describe the posteruption physical, chemical, and biological conditions in the western Washington study lakes near the volcano; determine the changes in the water quality and physical characteristics of previously existing lakes brought about by the eruption and relate them when possible to distance from the volcano; to monitor the recovery of these lakes; and to document the developing characteristics of the two new lakes. 
This report discusses the effects of the May 18, 1980, eruption on the physical, chemical, and blological characteristics of selected western Washington study lakes: four lakes within the blast zone of the volcano-Spirit, St. Helens, Venus, and Fawn Lakes--and two lakes outside of the blast zone--Deadmans and Walupt Lakes. The 1imnology of the two new lakes--

Coldwater and Castle Lakes--is also included in the report. The 3-year study began in June 1980 and ended in August 1982. Data collection at Deadmans, Coldwater, and Castle Lakes began in Spring 1981.

Limited background data for Spirit, Venus, Fawn, and Walupt Lakes are contained in Washington Department of Ecology Bulletin 43, v. 4 (Bortleson and others, 1976). Additional data are available for Walupt and Spirit Lakes in Washington Department of Ecology Bulletin 42, part 2 (Bortleson and others, 1974) and part 5 (Dion and others, 1976), respectively. No documented studies of St. Helens and Deadmans Lakes were available prior to this investigation. 


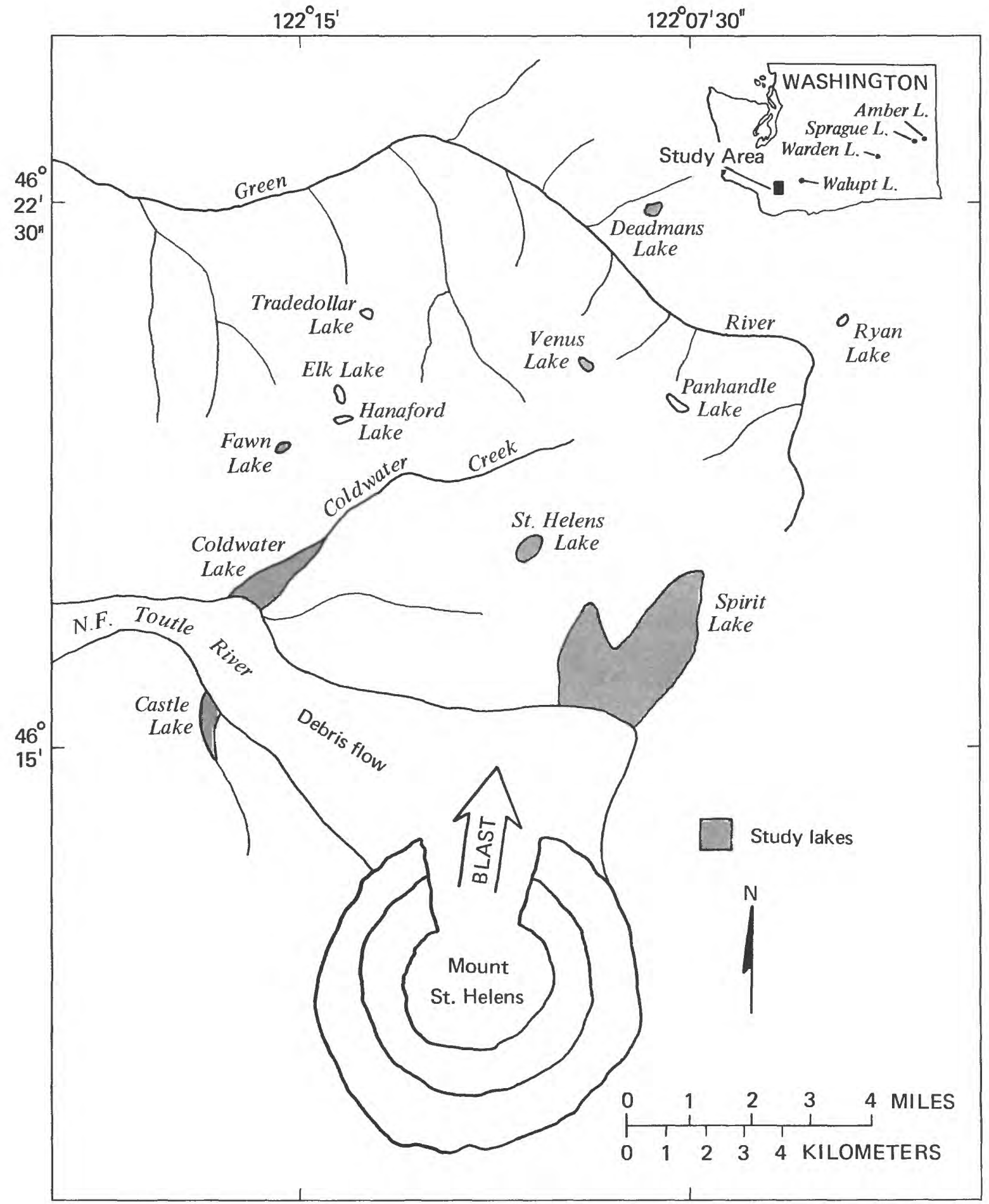

Figure 1.--Location of the study area and study lakes affected by the May 18, 1980, eruption of Mount St. Helens, Washington. 
Field visits to the lakes began in June 1980 and ended in August 1982. Data were collected approximately once a month from May through early October during the ice-free period. Dates of collection for individual lakes along with selected physical features of each lake are given in table 1 . Water samples for chemical and biological analyses, and in-situ measurements of 1ight, temperature, and dissolved oxygen were taken from a boat over the deepest part of each lake, which in most instances was near the center of the lake.

Vertical profiles of dissolyed oxygen and temperature were determined with a Yellow Springs Instrument Model 57 Oxygen Meter. Secchi-disc readings, used as a measure of water transparency, were made according to Welch (1948), and incident light and light transmission were measured with an underwater photometer. Color was described qualitatively according to how the lake water appeared against the white background sections of the Secchi-disc.

Water samples for determination of inorganic chemical constituents were collected with a 3-1iter plastic Van Dorn sampler, 3 feet below the water surface and 3 feet above the lake bottom. Specific conductance and $\mathrm{pH}$ were measured on subsamples using a Lab-Line (Model MC1) conductance meter and an Orion (Model 407A) $\mathrm{pH}$ meter, respectively. Techniques of sample preparation, sample preservation, and analytical procedures followed standard U. S. Geological Survey methods outlined by Skougstad and others (1979).

Phytoplankton and chlorophyll a samples consisted of composited subsamples of water collected with the Van Dorn sampler at several depths in the euphotic zone, defined in this report as the water layer bounded by the lake surface and the depth to where light intensity is equal to 1 percent of the surface incident light. The sampling interval was every 3 feet except in Deadmans Lake, in which the interval was variable due to the greater light transmission depths. During periods of maximum transparency in Deadmans Lake, at least five samples were collected from the entire water column.

Algae were identifled to species when possible, generally using the taxonomic keys of Prescott (1962, 1970, 1978). Chlorophyl1 a and pheophytin a (the latter analysis initiated in July 1981) were determined by the spectrophotometric (trichromatic) method outlined by American Public Health Association and others (1980). The quantity of volcanic and organic debris in the lakes interfered with analytical procedures that measure pigment; therefore, beginning in July 1981 water samples were filtered through glassfiber filters instead of cellulose-acetate filters.

Zooplankton were collected with a 153-micrometer cup screen and silk net during a single vertical tow from the lake bottom to the water surface. Zooplankton were identified to species when possible, generally using the taxonomic keys of Pennak (1953) and Ward and Whipple (1959).

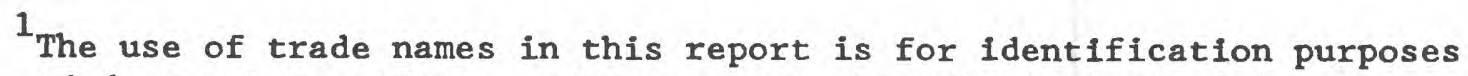
only and does not constitute endorsement by the U.S. Geological Survey. 


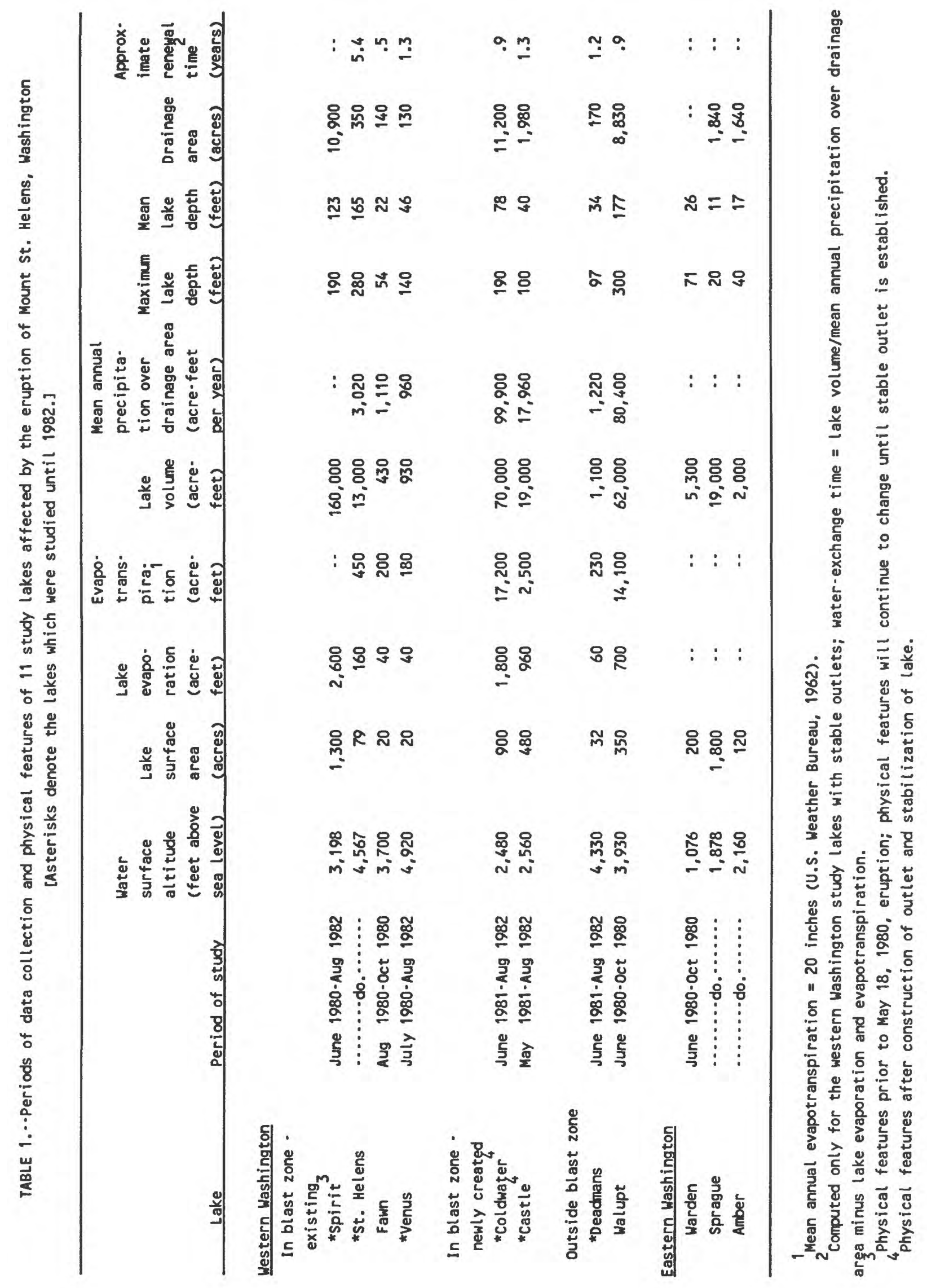




\section{MAJOR EFFECTS ON EXISTING STUDY LAKES IN WESTERN WASHINGTON, MAY 1980 TO OCTOBER 1980}

The study lakes that existed before the eruption and lie in the blast zone of the volcano recelved varying amounts of debris: avalanche, pyroclastic materials, ash, ice, and downed timber. Spirit Lake, closest to the volcano, was affected the most. A comparison of aerlal photographs taken before and after the eruption shows that the lake increased from 1,300 acres to about 2,200 acres and the lake surface was raised about 230 feet higher than its original altitude ( $\mathrm{fig} .2$ ). The higher altitude of the lake is due to the blockage of the North Fork Toutle River, floods from melting snow and ice on the volcanic cone, and partial filling of the original lake basin with debris (Youd and others, 1981). A bathymetric map of the lake completed since the eruption (Meyer and Carpenter, 1983) indicates that the maximum depth of the lake decreased from 190 feet to about 110 feet as a result of the eruption, and that the lake volume remained nearly the same.

The water in Spirit Lake was heated to more than $32{ }^{\circ} \mathrm{C}$ by the influx of hot volcanic material during the eruption on May 18, 1980, but the surface temperature had decreased to near preeruption levels $\left(13^{\circ} \mathrm{C}\right.$ ) by october 16 , 1980. Because of this heating and the change in the lake's altitude, Spirit Lake can be considered a completely different lake after May 18, 1980.

St. Helens Lake is also directly north of the volcano and in the direct line of the initial blast, but is at a higher altitude than Spirit Lake and did not receive a direct flow of avalanche material. All the trees in this lake basin were blown down, and many rolled into the lake. Considerable volcanic material fell into the lake or slid into it from the steep surrounding slopes. The outlet of the lake, which allows water to flow across a bedrock lip and into spirit Lake, appears to have been unaffected. Water was observed flowing out of the lake when it was first visited in July 1980. A posteruption bathymetric map of St. Helens Lake (fig. 3) indicates that it is 285 feet deep.

Venus Lake, about 10 miles north of the volcano, recelved heavy deposits of ash from the eruption. Most nearby trees were either blown down or completely stripped of bark, branches, and leaves, but the logs were not blown into the lake probably because of the greater distance from the volcano and the cushioning effect of intervening high ridges. The altitude of the lake surface was unchanged by the eruption, and when the lake was first visited in July 1980 water was draining through the outlet. Comparisons of pre and posteruption bathymetric maps indicate that the lake basin had not changed measurably, despite the deposition of ash.

One of the most obvious effects of the eruption on the lakes within the blast zone was reduced light transmission through the water column because of organic and inorganic debris in the lakes. Two types of optical conditions were observed that deviated from the clear-blue, preeruption condition in the study lakes: (1) water severely turbid and gray in color from suspended particulate matter, typified by St. Helens and Venus Lakes; and (2) water relatively clear but intensely brown-stained from dissolved organic material, typified by Spirit Lake. 

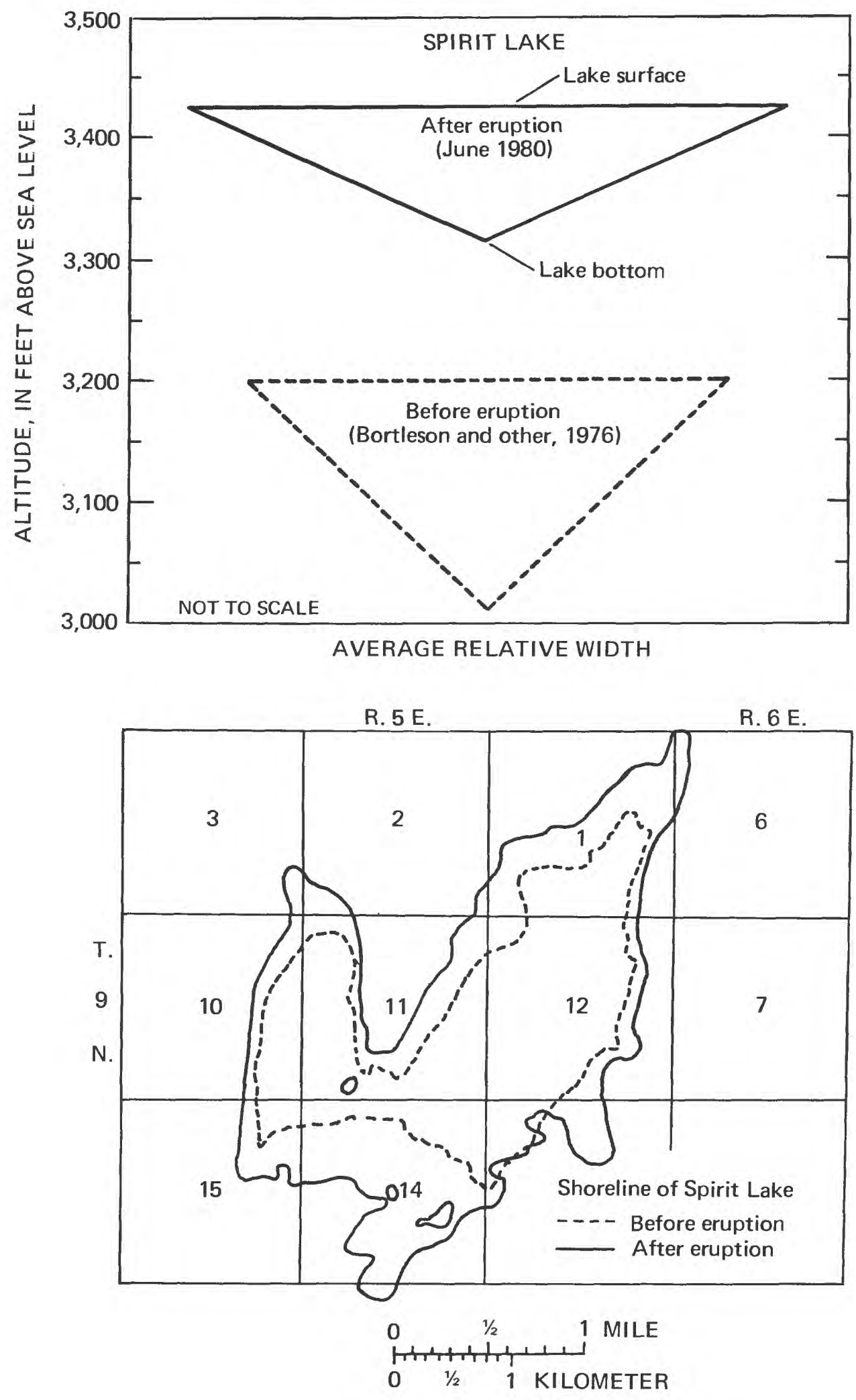

Figure 2.--Change in Spirit Lake before and after the May 18, 1980, eruption of Mount St. Helens, Washington. 
Increased concentrations of total and dissolved organic and inorganic chemicals dramatically changed the chemical character of Spirit, Fawn, and Venus Lakes, but essentially did not change the chemistry of Walupt Lake, 37 miles northeast of the volcano (Dion and Embrey, 1981). The concentrations of dissolved solids observed after the eruption in 1980 ranged from 2 to 30 times the concentrations measured in 1971 and 1974. Water-quality data (nearsurface samples only) for the four lakes with preeruption data are shown in table 2 with data collected in 1980 after the May 18 eruption. Chemical data for water samples taken near the bottom of the lakes not shown in this report can be obtained from U. S. Geological Survey computer files.

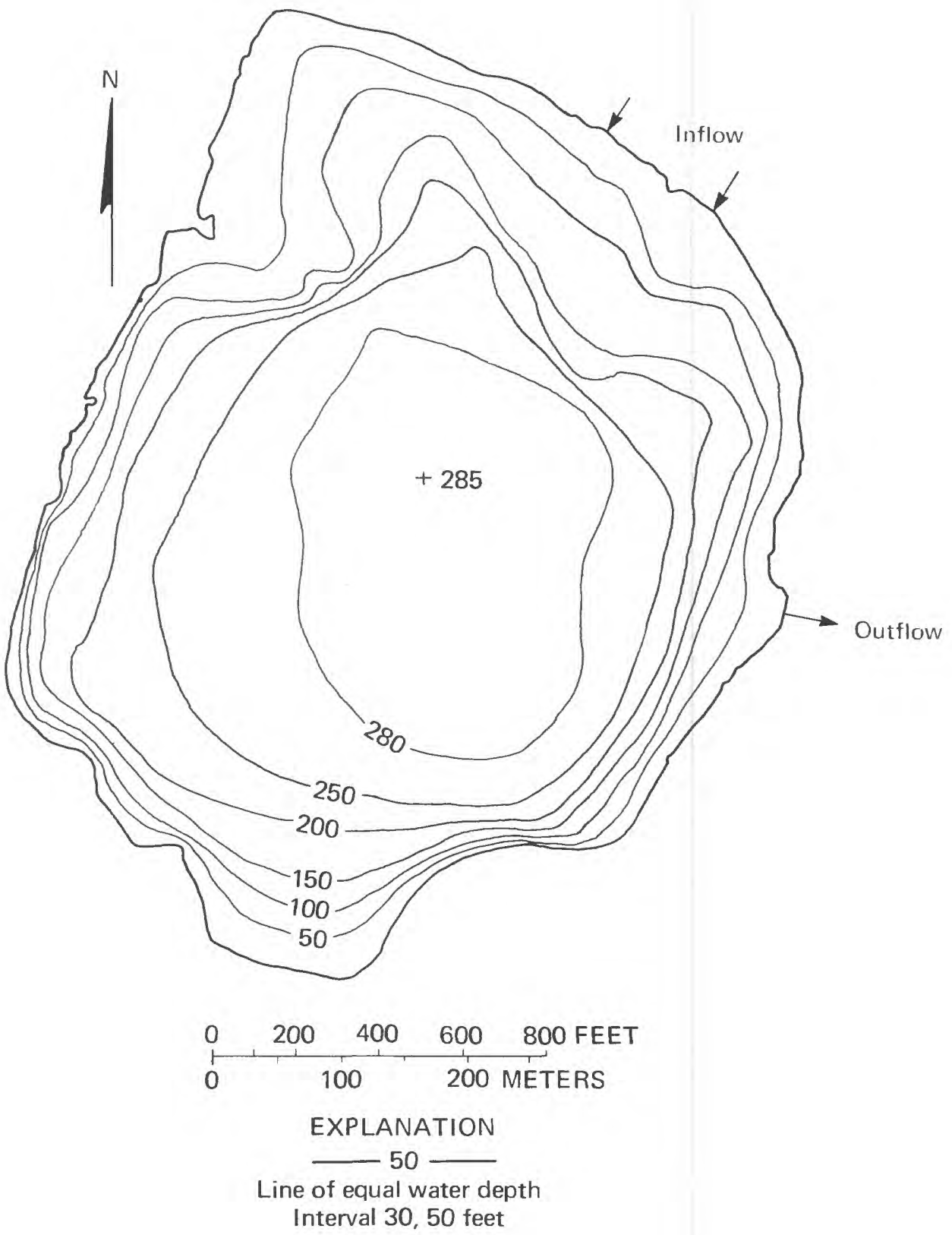

Figure 3.--Bathymetric map of St. Helens Lake after the May 18, 1980, eruption of Mount St. Helens, Washington. 


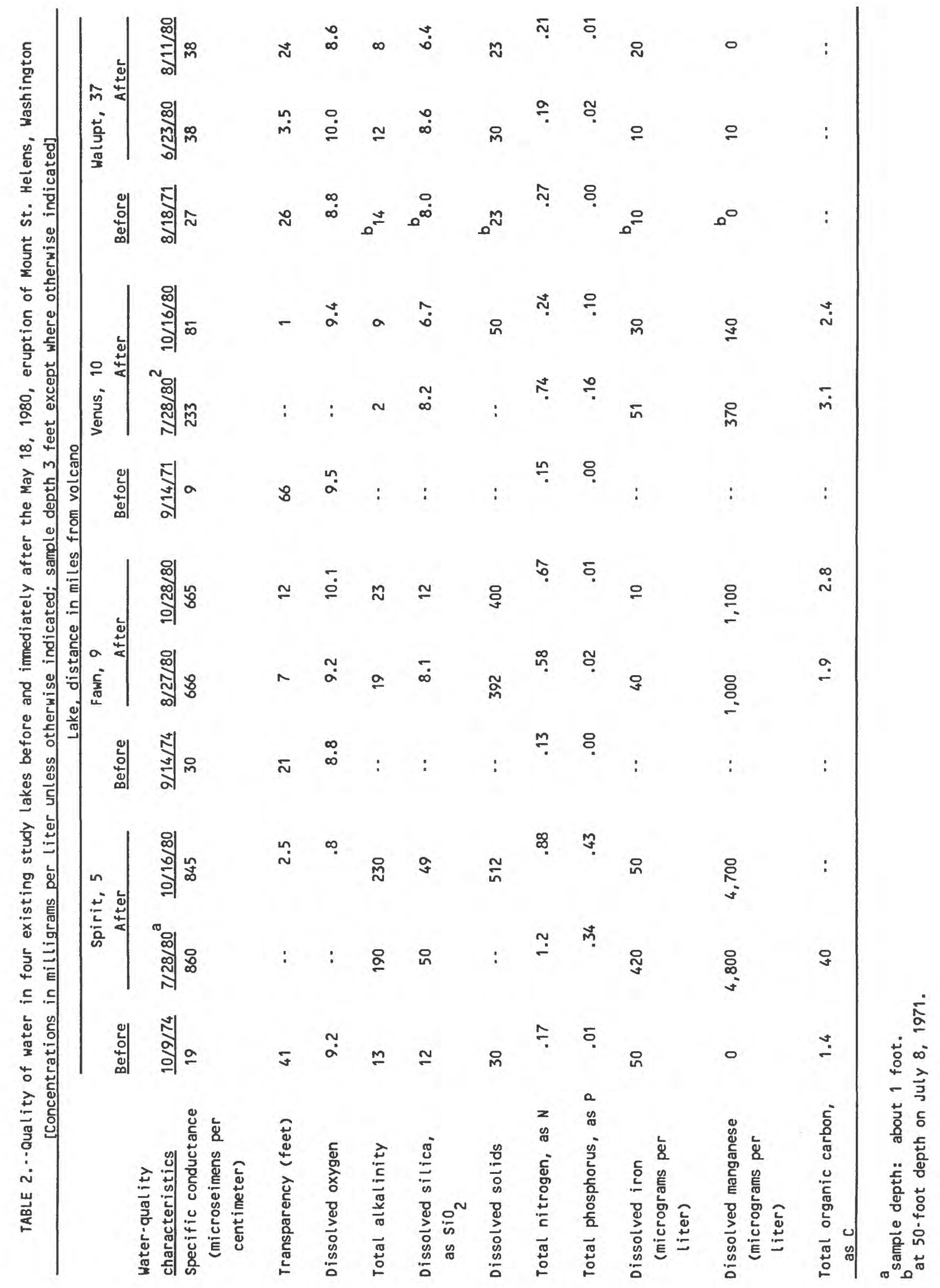




\section{POSTERUPTION PHYSICAL, CHEMICAL, AND BIOLOGICAL CONDITIONS}

IN EXISTING AND NEWLY CREATED STUDY LAKES IN WESTERN WASHINGTON, JUNE 1980 TO AUGUST 1982

The posteruption physical, chemical, and biological conditions of Spirit, St. Helens, Venus, and Deadmans Lakes varied according to their distance from the volcano and the initial degree of effect in 1980. Varying conditions from 1980 to 1982 in the lakes were probably due in part to the water-exchange times (time required for the water volume to be replaced by an equal volume of water from inflows) for each lake. Conditions in Coldwater and Castle Lakes, because they are newly formed, are compared only to each other and not with the existing lakes.

\section{Physical Characteristics}

Deadmans Lake, about 13 miles north of the volcano, received 2 to 3 inches of ash, but the lake is outside the scorched-tree zone, and accordingly, vegetation was not damaged. Although no preeruption bathymetric map of the lake is available, the morphometric characteristics, such as maximum depth and volume, of the lake probably did not change measurably as a result of the ash deposition. A posteruption bathymetric map of Deadmans Lake is shown in figure 4 .

During 1981, the U. S. Army Corps of Engineers constructed an outflow channel for Coldwater Lake during the summer and for Castle Lake in late autumn; this stabilized the lakes and reduced the possibility that they could overflow the debris dam and cause flooding downstream. Bathymetric maps for stabilized Coldwater and Castle Lakes are shown in figures 5 and 6 , respectively. In autumn 1982 the Corps of Engineers began pumping water from Spirit Lake and routing it to North Fork Toutle River to stabilize that lake.

\section{Water Transparency and Color}

The eruption and subsequent deposition of ash and debris substantially reduced water transparency and changed water color from blue to a variety of grays and browns in all four preexisting lakes. These conditions improved during the study as the result of dilution and the settling of suspended material to the lake bottoms.

The transparency of Spirit Lake was greatly reduced by the introduction of partially degraded lignin molecules and other pyrolized (chemically changed by heat) organic material (Pereira and others, 1982). Water transparency depth as measured by Secchi disc was 46 feet in September 1974, but only 2.5 feet in late 1980, and never exceeded 3.5 feet through September 1981 . By August 1982, however, the transparency had increased to 14 feet (fig. 7). Over the course of this study, the color of the lake water slowly improved from nearly black to a brown resembling that of strong tea. 

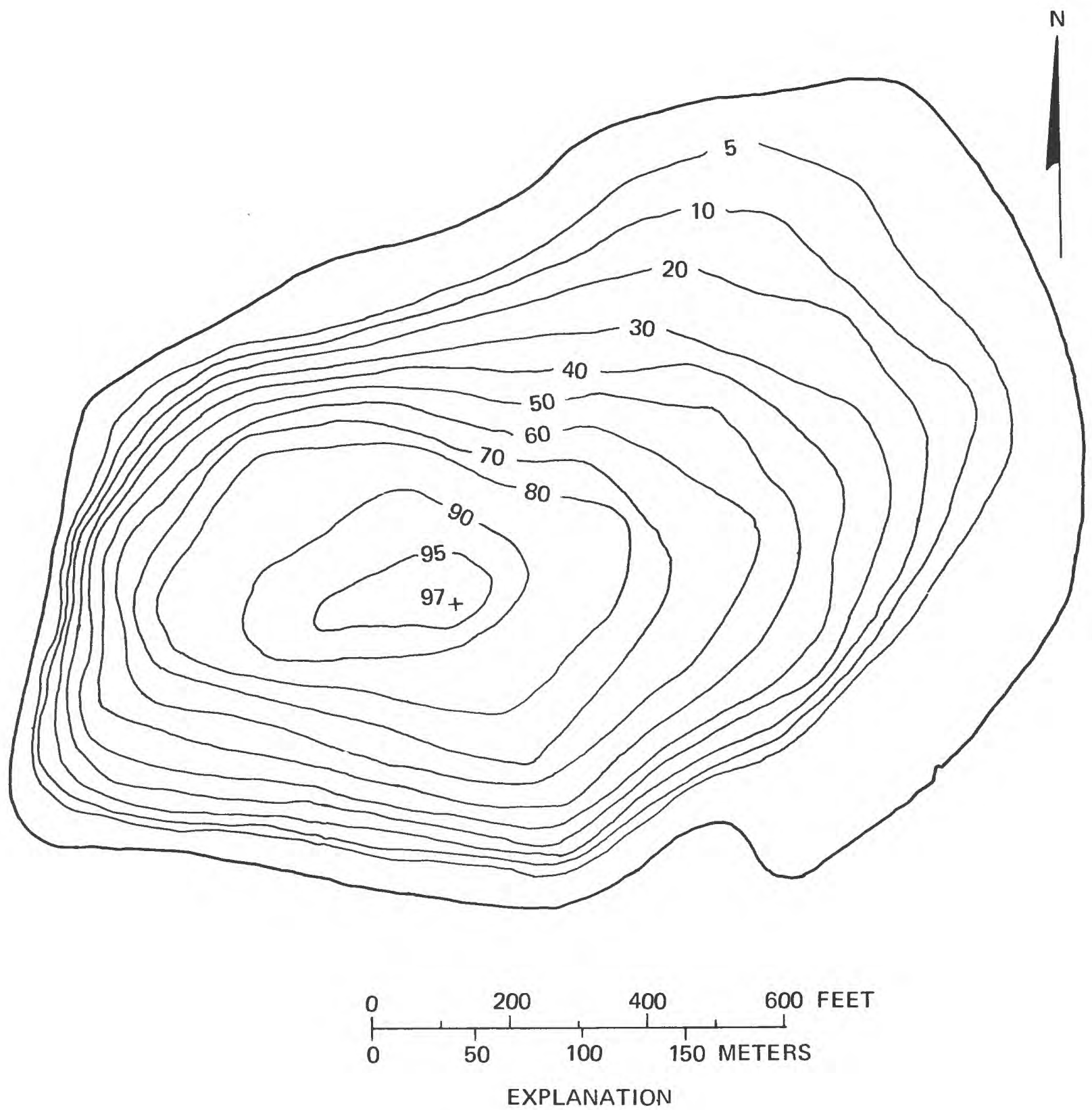

10

Line of equal water depth

Interval 5, 10 feet

Figure 4.--Bathymetric map of Deadmans Lake after the May 18, 1980, eruption of Mount St. Helens, Washington. 


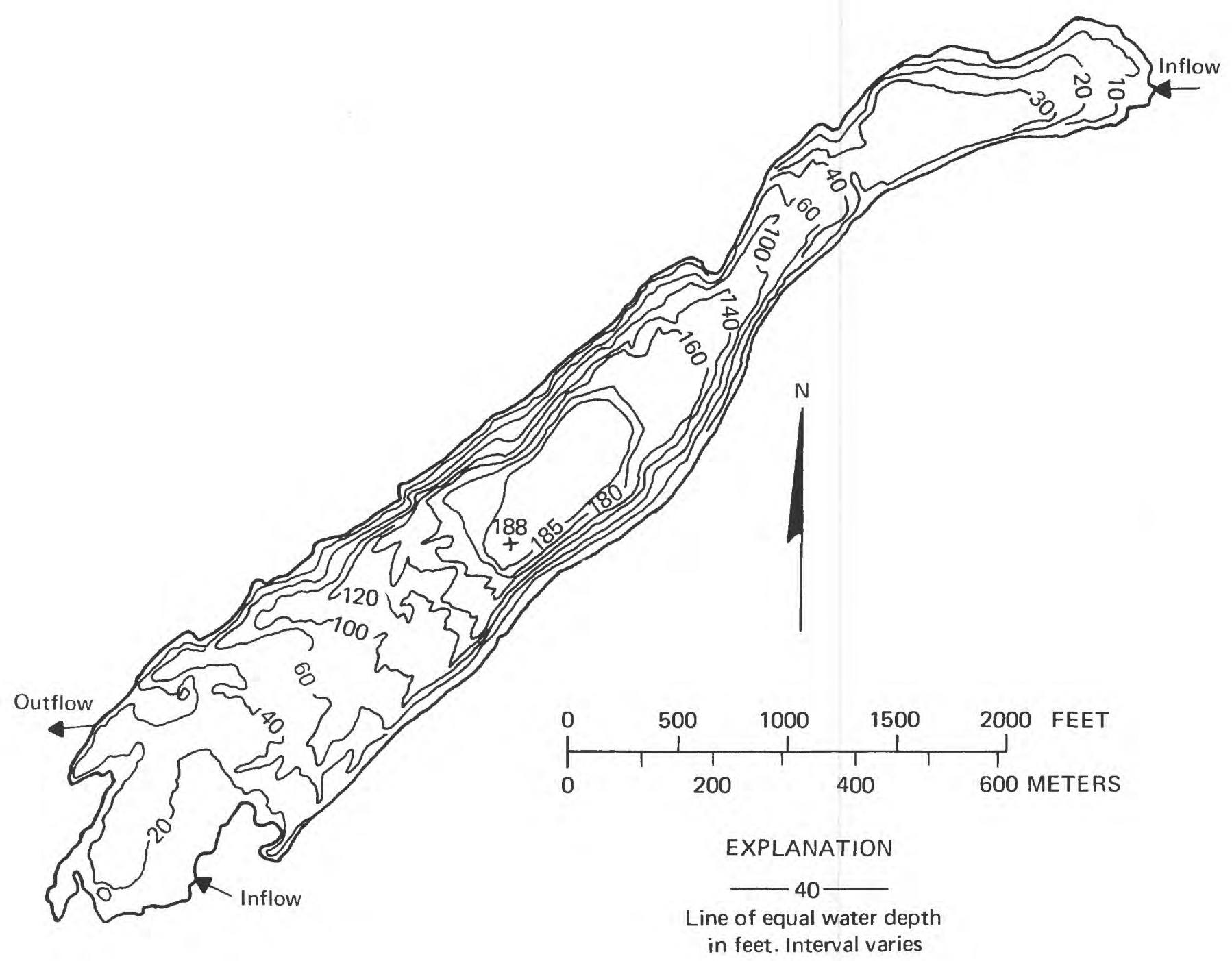

Figure 5.--Bathymetric map of coldwater Lake after the construction of outflow channel, November 1981. 


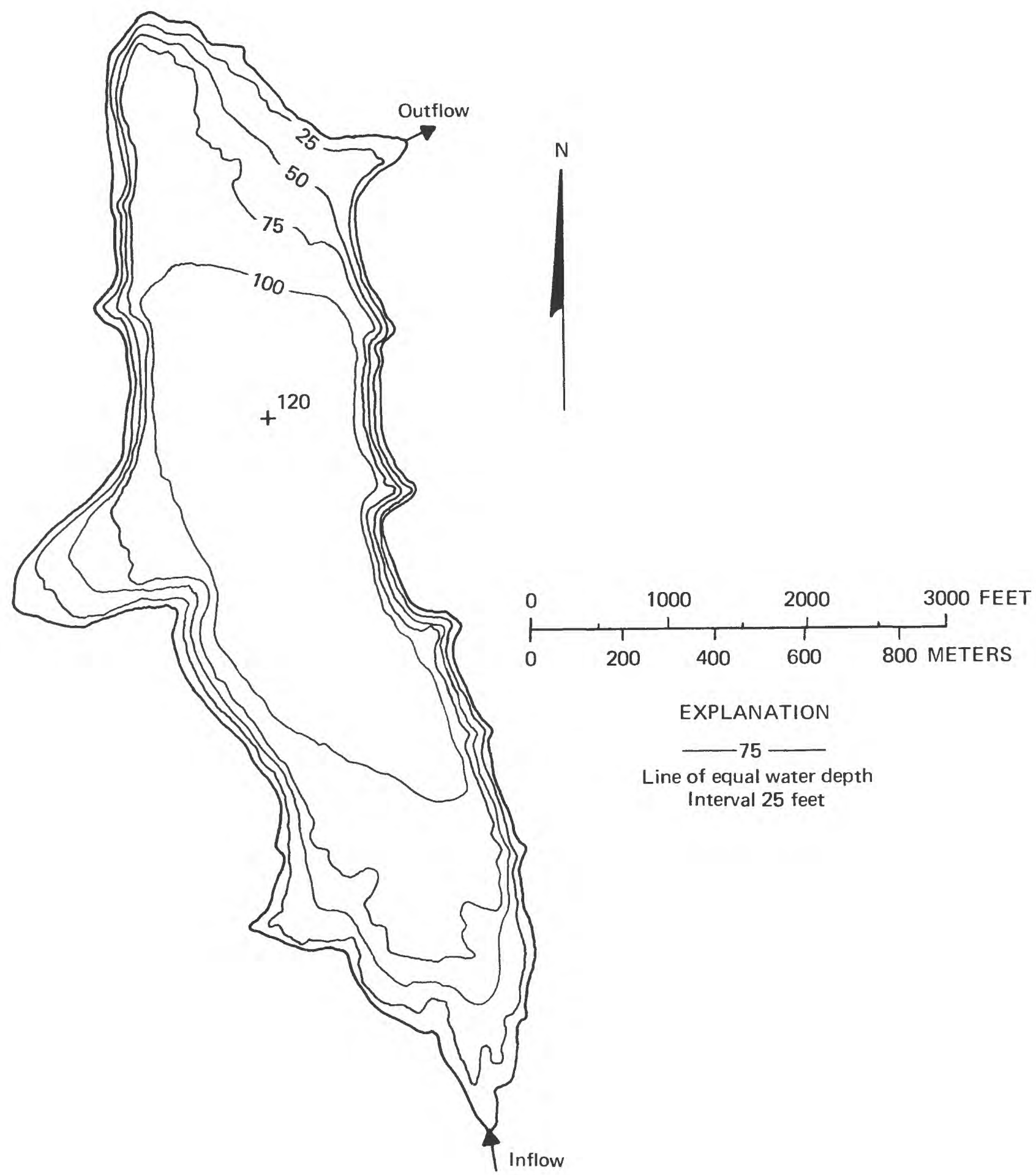

Figure 6.--Bathymetric map of Castle Lake after the construction of outflow channe1, November 1981. 
NEWLY CREATED LAKES
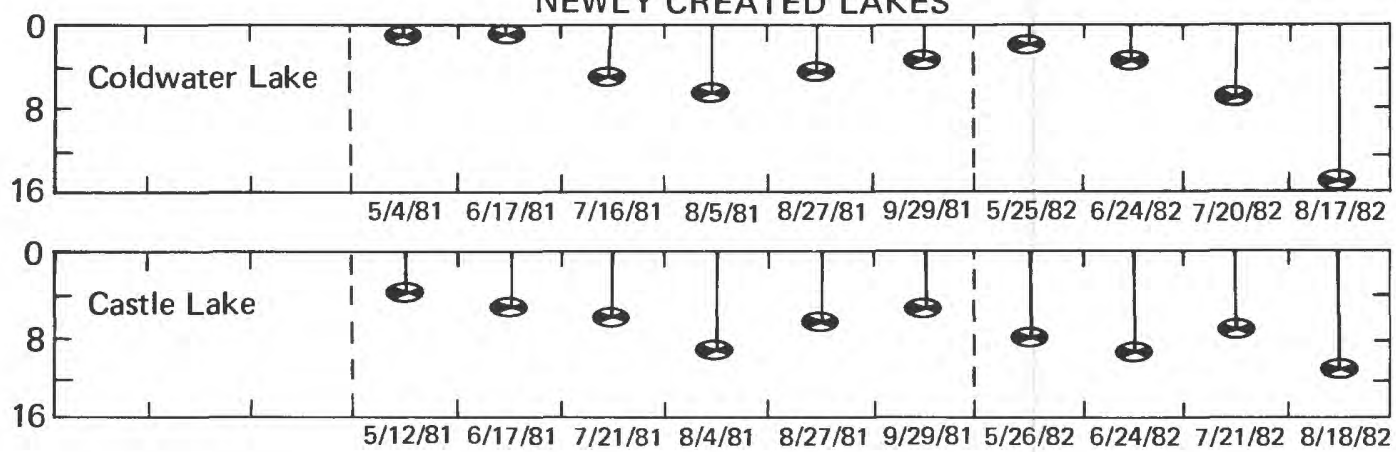

PRE-EXISTING LAKES
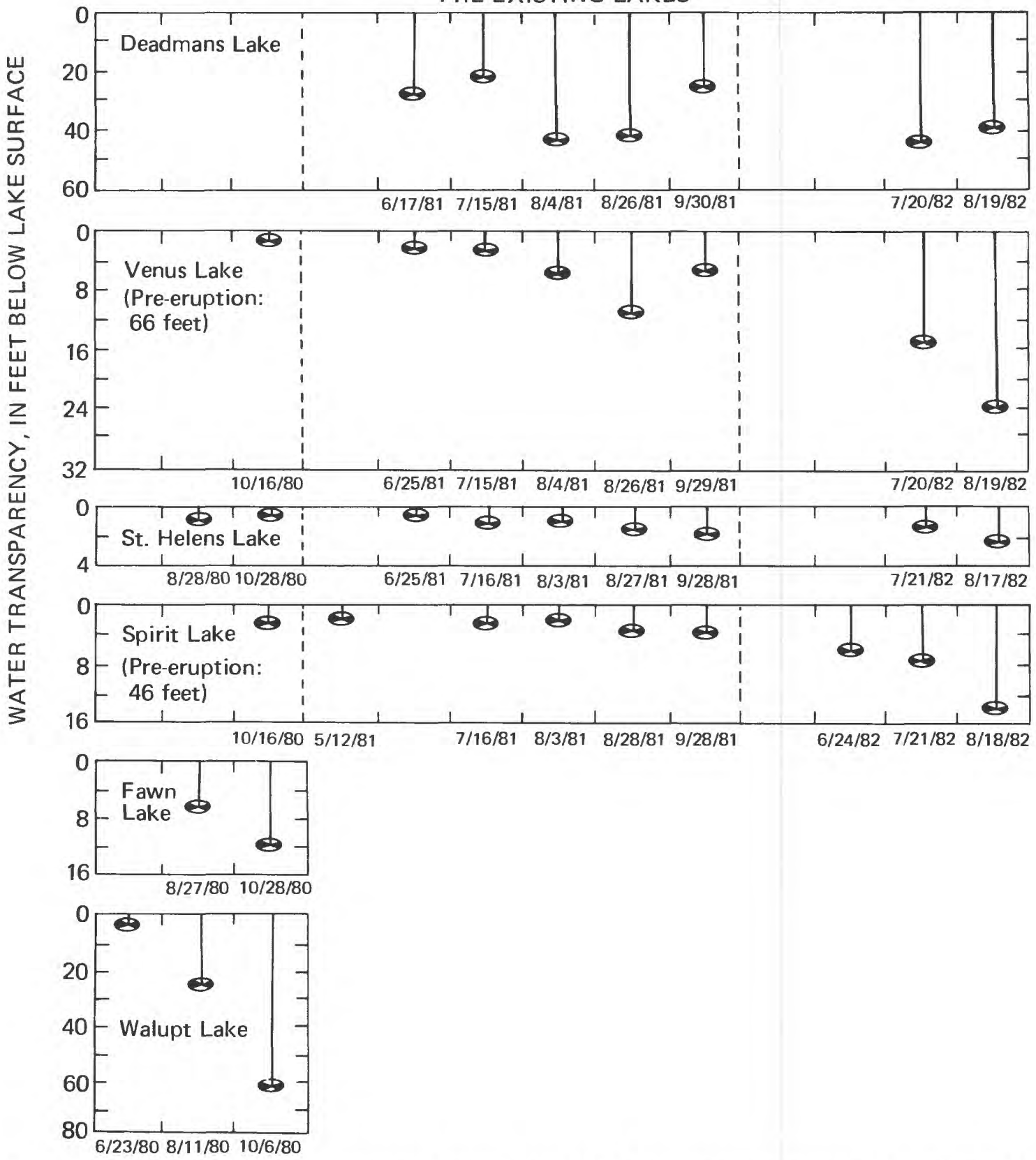

Figure 7.--Water transparency from Secchi disc measurements in study lakes near Mount St. Helens, Washington, June 1980 to August 1982. 
In St. Helens Lake, fine-grained suspended particulate matter, introduced at the time of the eruption, colored the water gray-brown and reduced the transparency to a depth of only 6 inches. By August 1982 the color had changed to yellow-green and the transparency had increased to a depth of only 2.5 feet (fig. 7). This lake, which showed the least improvement in transparency, has the longest estimated water-exchange time ( 5.4 years) of the study lakes (see table 1 ).

Venus Lake was described in 1974 as blue-green with a water transparency of 66 feet. Immediately after the 1980 eruption the water of Venus Lake was olive-brown and transparency was only 1 foot. During 1981 the water changed to gray-green, then to green, and the transparency increased to $11 \mathrm{feet}$. By summer 1982 the water was blue and transparency was 24 feet. This lake, about 10 miles north of the volcano, showed the greatest recovery in transparency of the blast-zone study lakes.

Although preeruption data are not available for Deadmans Lake, it was assumed to be similar to Venus Lake. Water transparency between June 1981 and August 1982 ranged from 22 to 44 feet and showed a general increase with time. Transparency tended to be less during spring runoff, when ash was likely being carried from the watershed to the lake, than during drier summer months. The water of Deadmans Lake was turquoise blue throughout the study period.

Water transparency in Coldwater Lake improved from a minimum depth of 1 foot during May and June 1981 to a maximum of 15 feet in mid-August 1982 . During the same period the transparency in Castle Lake improved from 4 to 11 feet. In general, however, water transparencies in amber-stained Castle Lake were greater than in turbid Coldwater Lake.

\section{Chemical Characteristics}

\section{Dissolved Oxygen}

Before the 1980 eruption, summer profiles of dissolved-oxygen (DO) concentrations in Spirit, Fawn, Venus, and Walupt Lakes were higher in the metalimnion (the layer of water between the epilimnion and hypolimnion and characterized by rapidly varying temperatures with increasing depth) than in either the epilimnion or hypolimnion (the cold layer of water near the lake bottom) (fig. 8). This profile shape, or positive heterograde curve, is common in clear lakes of moderate productivity and has been attributed to maximum production of oxygen in the metalimnion by photosynthesizing algae, to thermally related oxygen-saturation differences between the epilimnion and hypolimnion, or to some biological and chemical depletion of oxygen in the hypolimnion (Wetzel, 1975). 
In general, after the eruption, Do profiles in the blast-zone lakes were altered from a positive heterograde shape to a clinograde shape, characterized by relatively high DO concentrations in the epilimnion, rapidly decreasing DO through the metalimnion, and low or absent DO in the hypolimnion (fig. 8). Clinograde DO profiles have been associated with eutrophic lakes (Wetzel, 1975). Observed changes in the DO curves may have been due in part to reduced photosynthesis, and to the loading of chemically reduced organic and inorganic materials into the lakes, causing a depletion of oxygen in the hypolimnion. Dahm and others (1983), in a study of Ryan Lake 12 miles northeast of the volcano, suggest that immediately after the eruption a major portion of the soluble organic compounds from downed and pyrolized wood was metabolized by heterotrophic bacteria. This and related geochemical reactions helped deplete DO in that lake and likely in other blast-zone lakes.

Extreme heating and the introduction of avalanche, volcanic, and organic debris caused the water of Spirit Lake to become virtually devold of dissolved oxygen (anoxic) immediately following the eruption of May 18, 1980, and to remain depleted through fall 1980. The severe alterations to the thermal and DO characteristics of Spirit Lake Immediately after the eruption are discussed in detail in Dion and Embrey (1981). In May 1981 temperatures within the water column were relatively the same after spring overturn, and DO concentrations near the surface and near the bottom were 5.2 and $3.2 \mathrm{mg} / \mathrm{L}$ (milligrams per liter), respectively. By mid-July 1981, Spirit Lake had become thermally stratified and the Do profile had assumed a clinograde shape with a maximum observed DO concentration of $5.4 \mathrm{mg} / \mathrm{L}$ in the epilimnion, whereas the hypolimnion was anoxic. A similar distribution of DO existed during summer 1982 , except that DO concentrations in the epilimnion were about $2 \mathrm{mg} / \mathrm{L}$ 1arger than in 1981 and hypolimnetic anoxia occurred 1 month later than in 1981.

In high-altitude St. Helens and Venus Lakes, dissolved oxygen concentrations near the lake bottoms were smaller in 1982 than in 1981, possibly because the lakes were free of ice earlier in 1981, resulting in a longer mixing period during spring turnover. Bacterial activity and chemical oxidation in response to the Increased organic load may also have exerted a higher oxygen demand by 1982. Although Deadmans Lake was not sampled until mid-June 1981, the magnitude of Do concentration throughout the water column and the heterograde profile suggest that DO was unaffected by the eruption (fig. 8).

Coldwater and Castle Lakes developed clinograde DO profiles in 1981 and 1982. The hypolimnia in both lakes became depleted of oxygen during the summer of both years, probably due to a substantial biological and chemical oxygen demand from the breakdown of organic materials supplied by the newly inundated land, and to logs and other debris contributed to the new lake basins by the eruption. 

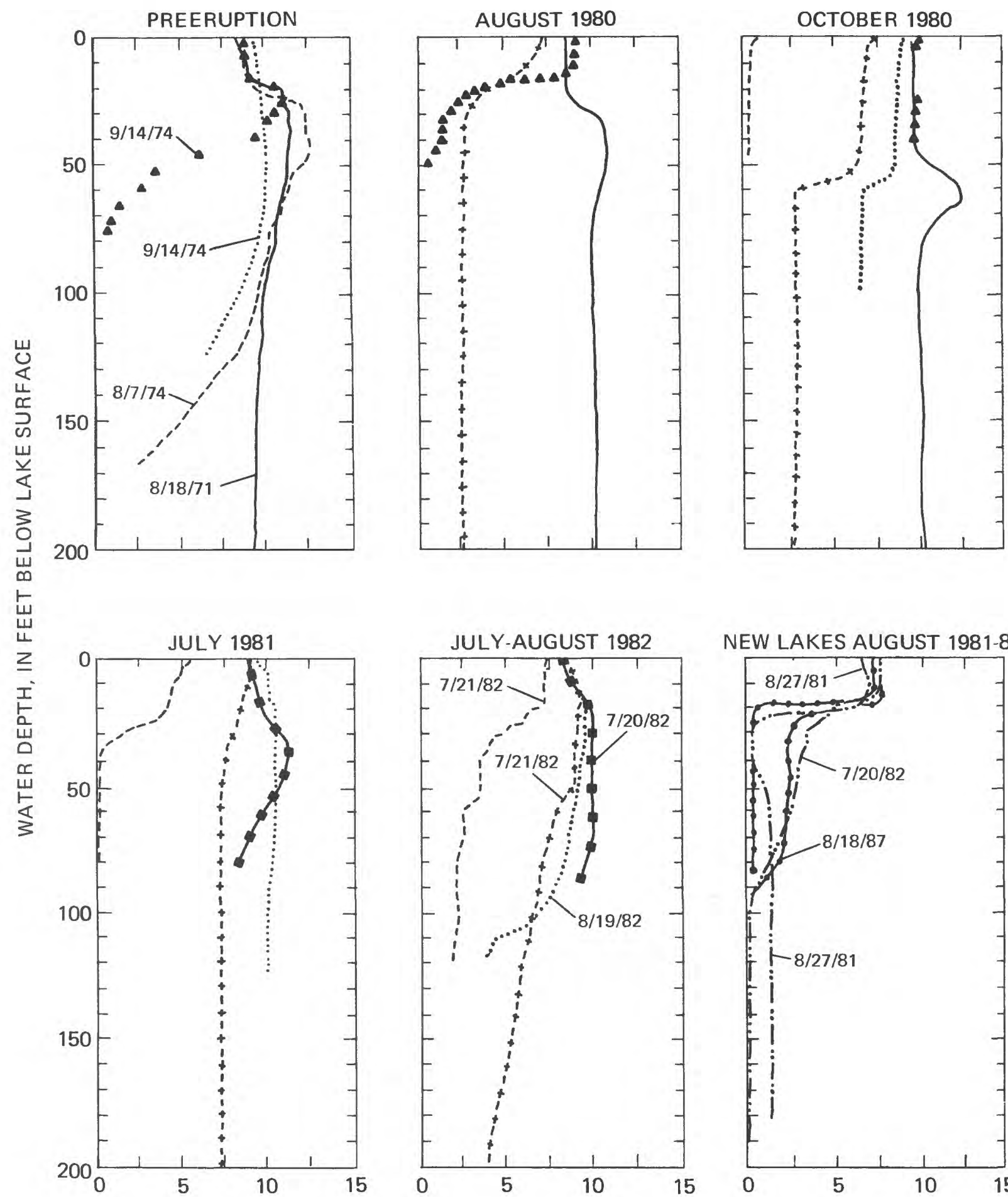

NEW LAKES AUGUST 1981-82

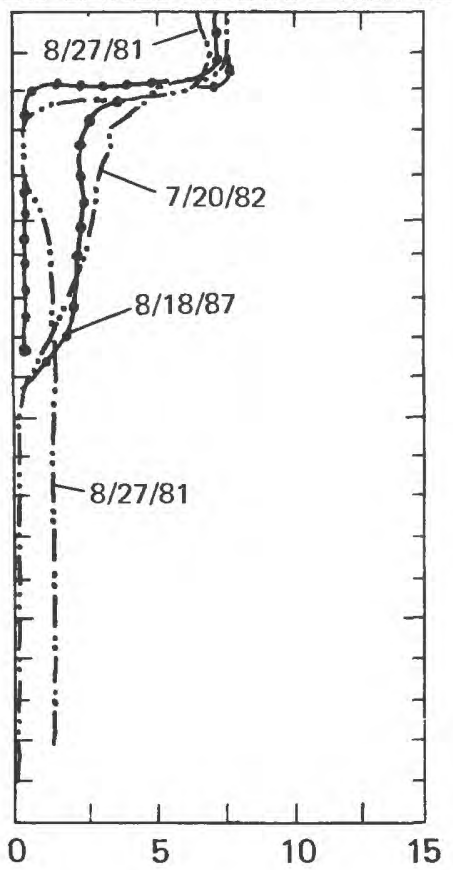

DISSOLVED-OXYGEN CONCENTRATION, IN MILLIGRAMS PER LITER

EXPLANATION

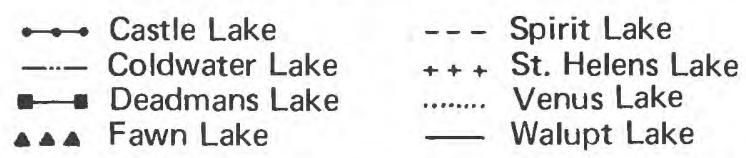

Figure 8.--Selected dissolved-oxygen profiles of study lakes before and after the May 18, 1980, eruption of Mount St. Helens, Washington. 


\section{Inorganic and Organic Chemistry}

Volcanic and other debris associated with the eruption affected the chemical composition of the study lakes to varying degrees (see table 2). Detailed descriptions of the debris are provided by Taylor and Lichte (1980), Sarna-Wojcicki and others (1980), and Waitt and Dzurisin (1981). All study lakes received varying amounts of volcanic ash, and Spirit, Coldwater, and Castle Lakes received some avalanche material containing large amounts of wood debris.

In general, concentrations of many constituents declined with a lake's distance from the volcano (fig. 9 and table 3 ). The effect of the eruption on the chemistry of Spirit Lake and, to a lesser degree, St. Helens Lake is particularly evident in the mean total concentrations of the major ions (cations and anions) for each yearly sampling period (fig. 9). In 1980 the average total concentrations, expressed in meq/L (milliequivalents per 1iter), were about 8.3 in Spirit Lake, 1.3 in St. Helens Lake, and 0.7 in Venus Lake. In 1981, the average concentrations decreased to about $6.5 \mathrm{meq} / \mathrm{L}$ in Spirit Lake and remained about the same in St. Helens Lake and Venus Lake. Deadmans Lake, representing minimal effects, had average total concentrations of about $0.5 \mathrm{meq} / \mathrm{L}$.

Lakes in the Mount St. Helens area were of the calcium-bicarbonate (Ca$\mathrm{HCO}_{3}$ ) water type prior to the 1980 eruption (Collings, 1973; Cummins, 1973; and Dion and others, 1976). Assuming that all the study lakes were similar before the eruption, the water types of all the lakes except Walupt were altered by the eruption (table 4). Walupt Lake was unchanged probably because of its distance from the volcano. In 1980, Venus Lake, the most distant and protected of the blast-zone study lakes, was a $\mathrm{Ca}-\mathrm{SO}_{4} / \mathrm{Cl}$ water type (calciumsulfate-chloride), whereas Fawn and St. Helens Lakes, closer to the volcano and less protected by ridges, were $\mathrm{Ca}-\mathrm{SO}_{4}$ (calcium-sulfate) types. Newly created Castle Lake had a $\mathrm{Ca}-\mathrm{HCO}_{3}$ water type when first measured after its formation and remained so throughout the study. The water type of nearby Coldwater Lake, which formed in the same manner as Castle Lake, was variable and essentially a mixed type ( $\mathrm{Ca} / \mathrm{Na}-\mathrm{SO}_{4} / \mathrm{Cl}$ ) during the study. Deadmans, Venus, and Spirit Lakes underwent gradual changes to a mixed water type throughout the study period.

The changes in the chemical water types of the lakes were largely a reflection of the composition of volcanic materials and debris introduced into the lakes at the time of eruption and the subsequent chemical and biological processes in the lakes. According to Sarna-Wojcicki and others (1980), the ash deposits associated with the eruption were generally higher in sodium than the average for the earth's crust. Leachate studies by Taylor and Lichte (1980) suggest that the water-soluble salts of chloride and sulfate were condensed onto the surfaces of ash particles and were therefore distributed over the area with air-fall deposits. These findings probably explain the role of sodium, chloride, and sulfate in the altered water types of affected 1akes. 
In the 1970 's, nutrient concentrations in the epilimnia of existing study lakes were at or below detection levels (phosphorus <0.01, nitrate-nitrogen $<0.10$, and ammonia nitrogen $<0.06 \mathrm{mg} / \mathrm{L}$ ). In the first samples collected after the eruption from Spirit, St. Helens, Venus, Fawn, and Walupt Lakes, total inorganic nitrogen concentrations were still essentially at the detection level, and dissolved phosphorus concentrations were only slightly above detection levels. In freshwater lake ecosystems, the growth of the algae or primary production is usually limited first by phosphorus (Welch, 1980). After the eruption primary production was probably limited to a greater extent by reduced light, increased metal concentrations, and competition with bacterial populations, than by small nutrient levels. As the lakes recover, concentrations of nitrogen and phosphorus will probably again become the first factors to limit primary productivity.

Concentrations of dissolved inorganic nitrogen and phosphorus at the time of spring overturn were evaluated with respect to Sawyer's threshold of 0.30 $\mathrm{mg} / \mathrm{L}$ nitrogen and $0.015 \mathrm{mg} / \mathrm{L}$ phosphorus (Welch, 1980, p. 125). For this study, data collected in May would approximate phosphorus and nitrogen concentrations during spring overturn. Only in the two new lakes, Castle and Coldwater, were nutrient concentrations in May 1982 large enough to exceed the threshold limits, thus implying a potential to develop summer algal blooms.

One dramatic change in the chemistry of the lakes was the increase in concentrations of dissolved organic carbon (DOC) and total organic carbon (TOC). TOC increased to about 20 times preeruption concentrations in spirit Lake and doubled in the other blast-zone lakes. The major source of the organic material was probably pyrolization of the coniferous forest that surrounded the volcano before the eruption. As with many other chemical constituents, the increase in TOC concentrations (table 3) was generally inversely related to the distance of a lake from the volcano.

In a detailed characterization of the dissolved organic compounds in blast-zone lakes, Mcknight and others (1982) identified aliphatic acids, phenol, cresol, resin acids, terpenes, and juvenile-insect hormones, and determined that hydrophobic and hydrophilic acids accounted for 29 and 30 percent of the DOC, respectively (D. McKnight, U. S. Geological Survey, oral commun., 1984). They also concluded that: (1) dilution and flushing may have a greater role in decreasing the DOC concentrations of the blast-zone lakes than does degradation by planktonic microorganisms, but that (2) dissolved organic material might continue to be supplied to the lakes by microbial degradation of organic bottom material and from dead trees and organic soil materials in the watersheds.

Throughout the study, concentrations of both iron and manganese were generally higher near the bottom of the lakes than near the surface, especially during the summer months when thermal stratification was well developed and dissolved-oxygen concentrations at depth were small or depleted. The widespread anoxic conditions observed in 1980 in lakes affected by the eruption mobilized high concentrations of iron and manganese into the water column. The most severely affected was Spirit Lake, where in July 1980 iron and manganese concentrations in the littoral (near shore) zone were 420 and 4,800 $\mu \mathrm{g} / \mathrm{L}$ (micrograms per liter), respectively (table 2). Concentrations of iron and manganese in all the lakes generally decreased with time during the period of study. 

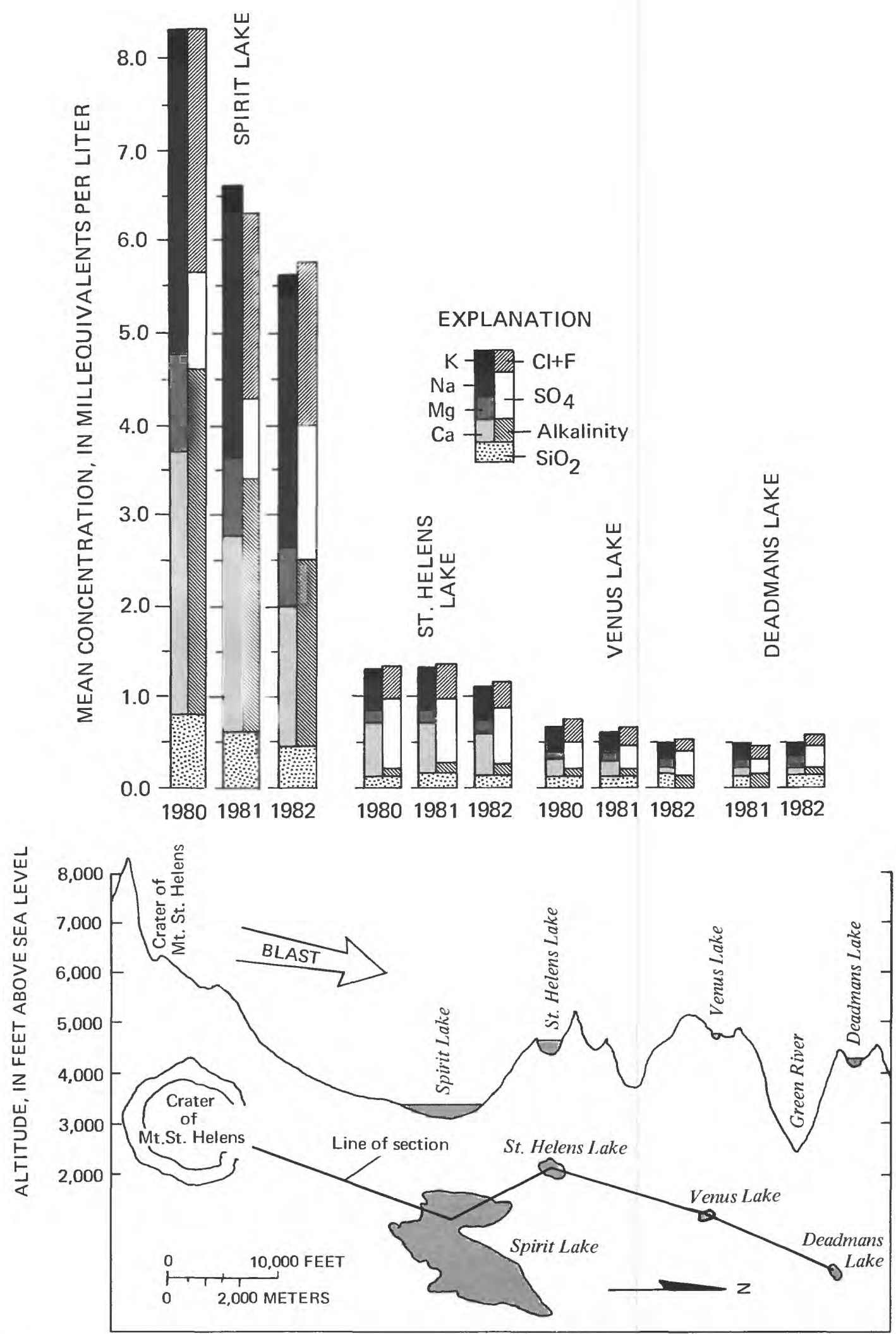

Vertical exaggeration $5 x$

Figure 9.--Major-ion concentrations in selected study lakes lying directly north of the volcano in the line of the eruption blast zone near Mount St. Helens, Washington. 


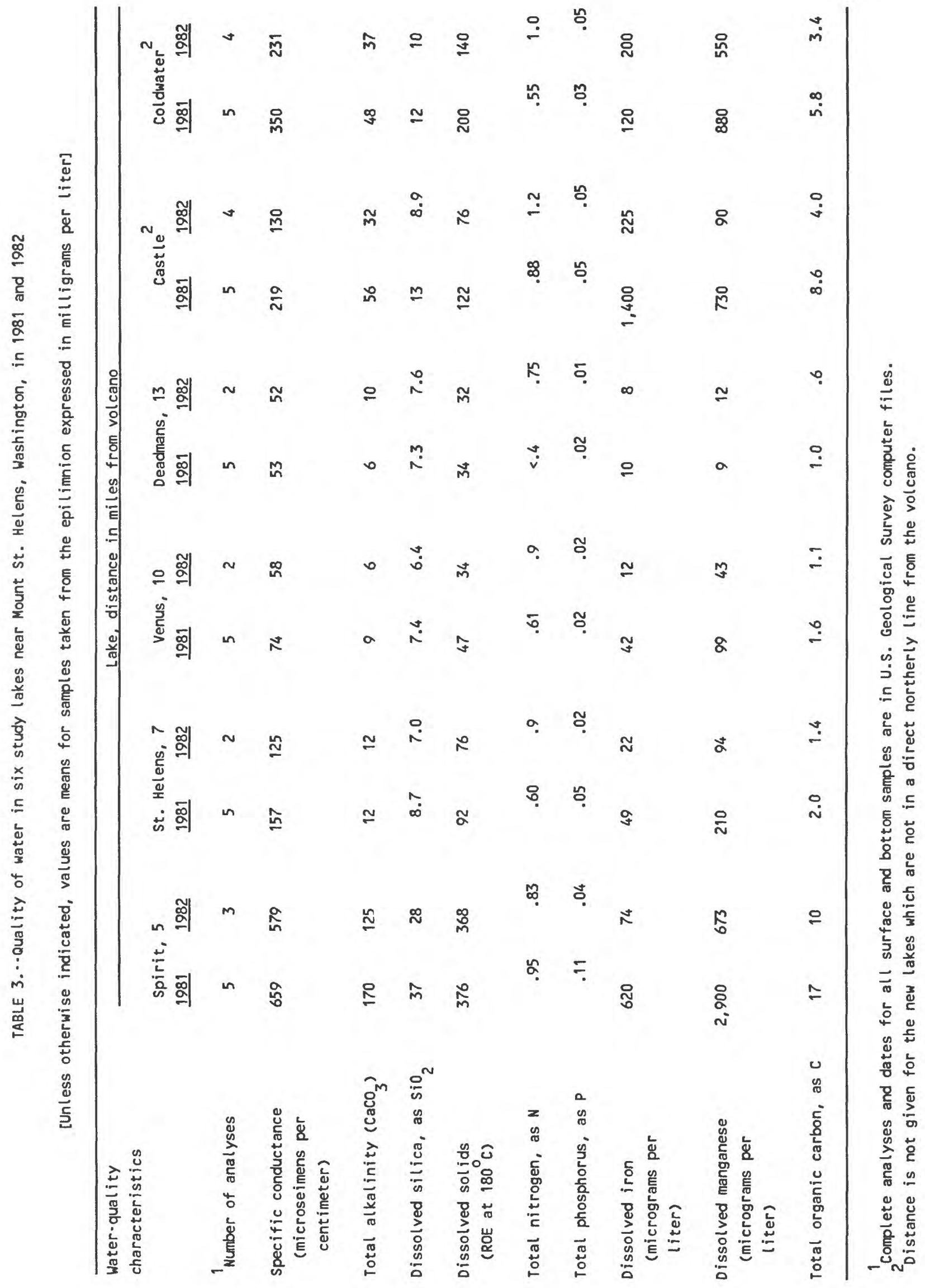




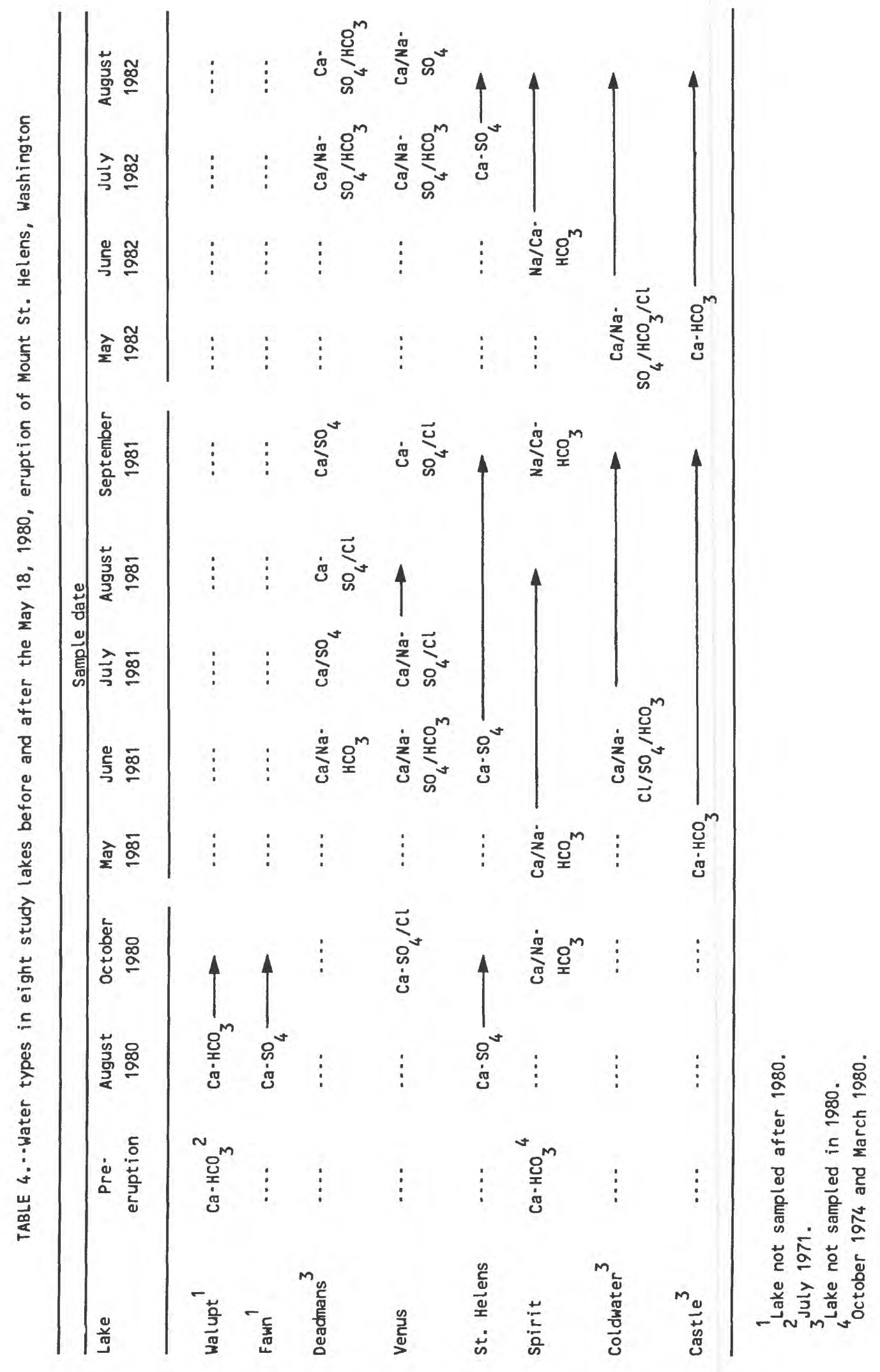




\section{Biological Characteristics}

Little preeruption information is avallable about the biology of lakes in the Mount St. Helens blast zone, and therefore the biological effects of the eruption can only be surmised. Uncorrected chlorophyll data, available only for Spirit Lake in 1974, ranged from 0.3 to $1.3 \mu \mathrm{g} / \mathrm{L}$. Qualitative and quantitative data pertaining to populations of phytoplankton and zooplankton are available for the posteruption period only.

\section{Chlorophyl1}

Chlorophyll a is a photosynthetic pigment present in all groups of algae, and pheophytin a is chlorophyl1 a that has been inactivated by the loss of a magnesium atom. The amount of pheophytin in relation to chlorophyll a can indicate the health of an algal population, whether it is in an active or declining growth phase. The quantity of chlorophyl1 a in a water sample provides an estimate of the biomass of algal populations and, as such, can be an indicator of the general productivity of a lake. Welch (1980) suggested using average summer corrected chlorophyll a concentration to classify the trophic status of lakes as follows:

\begin{tabular}{lc}
\hline $\begin{array}{l}\text { Trophic status } \\
\text { of lake }\end{array}$ & $\begin{array}{l}\text { Average summer chlorophy11 } \\
\text { a concentration, in micro- } \\
\text { grams per liter }\end{array}$ \\
\hline Oligotrophic & $0-4$ \\
Mesotrophic & $5-9$ \\
Eutrophic & $10-100$ \\
\hline
\end{tabular}

The largest concentrations of chlorophyll a and therefore estimates of the largest biomass were found in Castle Lake and ranged from 2.1 to $2.5 \mu \mathrm{g} / \mathrm{L}$ in 1981 and from 2.0 to $7.4 \mu \mathrm{g} / \mathrm{L}$ in 1982. The smallest concentrations, sometimes as small as zero, were found in Deadmans Lake (fig. 10). In Spirit, St. Helens, Venus, and Castle Lakes average chlorophyll a concentrations were greater during summer 1982 than in summer 1981 (table 5). Average chlorophyl1 a concentration in Castle Lake for summer 1982 was about three times that of 1981, and in Spirit Lake more than 10 times greater than in 1981 . By 1982 , Castle Lake, with an average summer chlorophyll a concentration of $6.6 \mu \mathrm{g} / \mathrm{L}$, could be considered mesotrophic according to Welch's classification. The remaining lakes, with average summer concentrations less than $4.0 \mu \mathrm{g} / \mathrm{L}$, would be considered oligotrophic.

Castle Lake also had smaller percentages of pheophytin a with respect to chlorophyll a than the other lakes, averaging 17 percent during summer 1981 and 11 percent during summer 1982 (table 5). These relatively small percentages of pheophytin a may indicate a particularly healthy and active population of phytoplankton in this lake. 

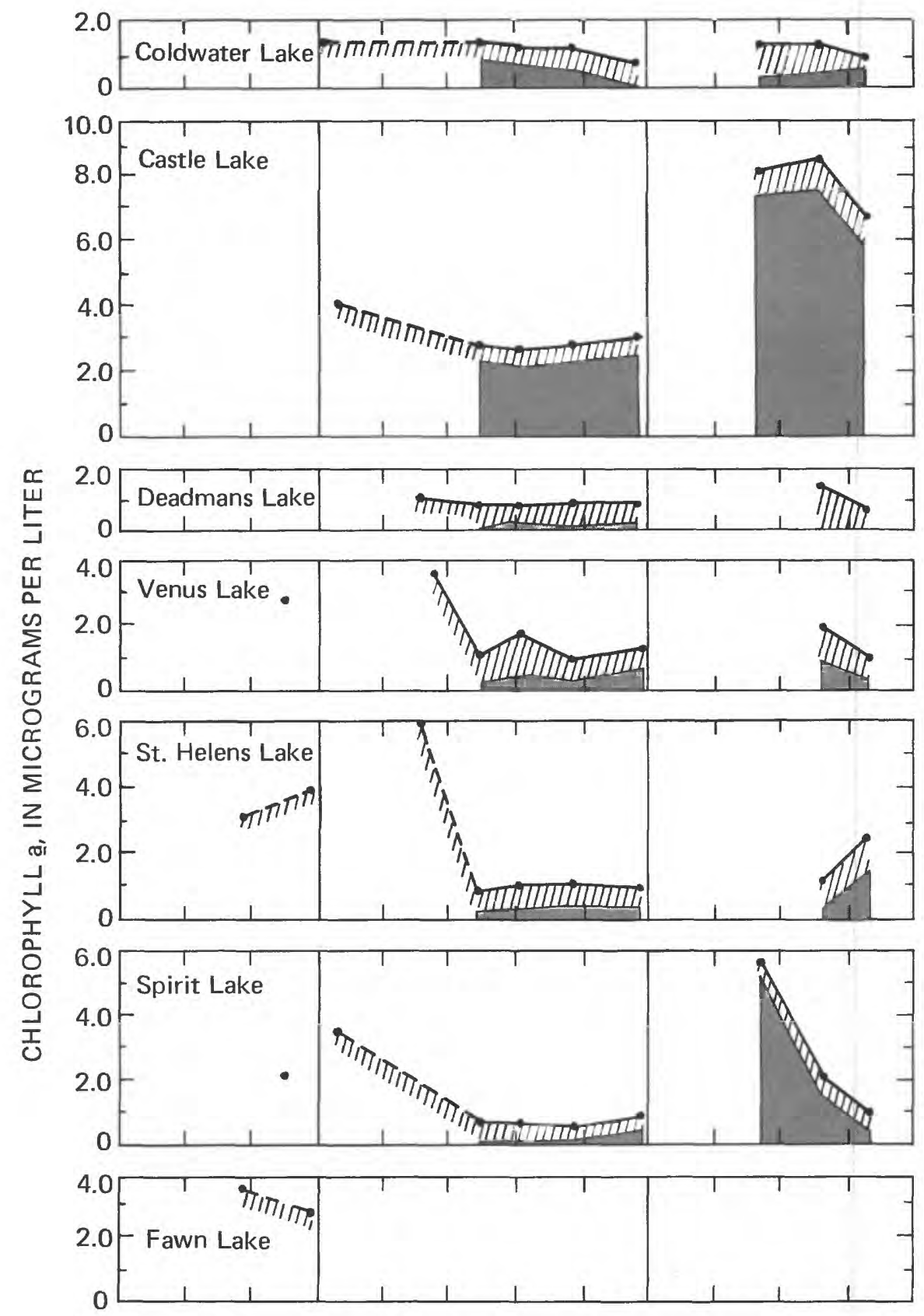

IIIII Chl. $\underline{a}$, Trichromatic

Chl. â, Corrected for Pheophytin $\underline{\text { a }}$

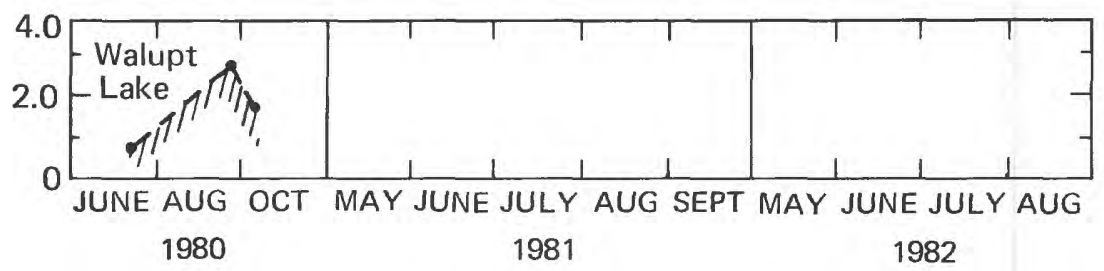

Figure 10.--Chlorophyl1 a concentrations in the study lakes near Mount St. Helens, Washington, June 1980 to August 1982. 
TABLE 5.--Average summer concentrations of chlorophyll a and average percentages of pheophytin a during summer 1981 and summer 1982 in six study lakes near Mount St. Helens, Washington

\begin{tabular}{|c|c|c|c|c|}
\hline \multirow[b]{2}{*}{ Lake } & \multicolumn{2}{|c|}{ July-August 1981} & \multicolumn{2}{|c|}{ July-August 1982} \\
\hline & $\begin{array}{l}\text { Chlorophyll a } \\
\text { (micrograms } \\
\text { per liter) }\end{array}$ & $\begin{array}{l}\text { Pheophytin a } \\
\text { in percent }\end{array}$ & $\begin{array}{c}\text { Chlorophyll a } \\
\text { (micrograms } \\
\text { per liter) }\end{array}$ & $\begin{array}{l}\text { Pheophytin a } \\
\text { in percent }\end{array}$ \\
\hline Castle & 2.23 & 17.3 & 6.60 & 11.3 \\
\hline Coldwater & .60 & 50.7 & .45 & 57.3 \\
\hline Spirit & .18 & 74.0 & .96 & 44.2 \\
\hline St. Helens & .41 & 60.3 & .93 & 54.8 \\
\hline Venus & .36 & 71.7 & .62 & 58.4 \\
\hline Deadmans & .19 & 73.0 & .00 & 100.0 \\
\hline
\end{tabular}

Phytoplankton

The phytoplankton community has been divided for the purposes of this report into four major groups of organisms: the green algae (chlorophyta), bluegreen algae (Cyanophyta or Cyanobacterla), yellowgreen algae (Chrysophyta), and a group of unidentifiable, mostly flagellated forms. The yellowgreen algae are further divided into the Bacillariophyceae (diatoms) and the Chrysophyceae including Dinobryon and Chlorochromonas (Ochromonas) species, three types of organisms that were prevalent in samples from the study lakes.

Only a few samples were collected for analysis of phytoplankton concentration and identification in 1980 after the eruption. A single sample from Spirit Lake, taken in October 1980, had the greatest concentration of phytoplankton, 15,000 million org/m (organisms per cubic meter) (fig. 11). This sample was composed almost entirely of a single species of bluegreen algae, Rhabdoderma lineare. By the spring of 1981 the concentration of algae in Spirit Lake was less than $20 \mathrm{million}$ org $/ \mathrm{m}^{3}$. Although $\mathrm{R}$. Iineare was found in samples during late summer 1981 and 1982, it was not in such large numbers as in 1980. Fawn Lake had the next largest concentrations of phytoplankton in 1980--3,410 million org/m in August, mostly the green flagellate Carteria sp. (species), and $898 \mathrm{million}$ org $/ \mathrm{m}^{3}$ in October, mostly the bluegreen Chroococcus dispersus. 
During 1981, Coldwater Lake had the smallest concentrations of phytoplankton of the study lakes, ranging from $224 \mathrm{million}$ org $/ \mathrm{m}^{3}$ in June to $20 \mathrm{million}$ org $/ \mathrm{m}^{3}$ in September. During 1982, concentrations in June were smallest in Coldwater Lake ( $40 \mathrm{million}$ org $/ \mathrm{m}^{3}$ ), but in $\mathrm{July}$ were smallest in Venus ${ }_{3}$ Lake $(43 \mathrm{million}$ org $/ \mathrm{m}$ ), and in August in Spirit Lake (145 million $\mathrm{org} / \mathrm{m}^{3}$ ). Algal concentrations in Castle Lake were greater during summer 1982 than summer 1981, and were generally greater than concentrations in the other lakes. The Indication of high productivity in Castle Lake, suggested also by the nutrient and chlorophy11 a concentrations previously discussed, was confirmed by the continued increase in phytoplankton concentrations during summer 1982 to a maximum of $7,600 \mathrm{million} \mathrm{org} / \mathrm{m}$ in July.

Despite restricted light transmission in St. Helens Lake, the concentrations of algae during ${ }_{3}$ the summers of 1981 and 1982 , ranging from 110 million to $1,090 \mathrm{million}$ org $/ \mathrm{m}$, were about the same as in the other lakes. Chlorochromonas species predominated during 1981 and diatom species in 1982.

The percentage composition of the phytoplankton community of each lake is presented in figure 12, and the dominant species for each sample are indicated In the taxonomic tables of appendix A. Assoclations of dominant algae have been used by limnologists to classify trophic levels of lakes and related water characteristics (Wetzel, 1975, p. 299), but these associations are not strongly evident in the phytoplankton communities of the study lakes. It has been suggested that there is a metabolic advantage of smallness and motility for organisms that inhabit oligotrophic lakes with water of small nutrient content (Wetzel, 1975, p. 309). Motile groups of algae were a large component of the algal communities of the lakes, especially during 1981. The Dinobryon species, which predominated in Walupt Lake and were present in Deadmans, Venus, St. Helens, Castle, and Spirit Lakes, have been shown to be generally restricted to water with a small $(<0.02 \mu \mathrm{g} / \mathrm{L}$ ) phosphorus content (Hutchinson, 1967; Wetze1, 1975). These same lakes, however, contained in their communities certain tolerant species and, occasionally, noted eutrophic Indicators such as Synedra spp., Fragilaria crotonensis, Asterionella spp., Eugelena, Anabaena, Microcystis, and some dinoflagellates.

In late 1980, the green and the bluegreen algae were generally the most prevalent groups in the existing blast-zone lakes. Outside of the blast zone, Walupt Lake, farthest from the volcano, was dominated nearly exclusively by Dinobryon bavaricum in June 1980, but by August 1980 the other groups of algae were present in greater percentages. During most of summer 1981, the phytoflagellates (including flagellated chlorophyta, chrysophyta, and unidentified forms) were present in larger numbers than the other types of algae in samples from the lakes. The phytoflagellate, Chlorochromonas sp. was found in all of the lakes sampled in 1981, and was frequently dominant or codominant in St. Helens, Venus, Coldwater, and Castle Lakes.

Compared to the phytoflagellates, the diatom populations were relatively small in all the blast-zone lakes, existing and newly created, until the summer of 1982 when they became dominant or co-dominant in Spirit, St. Helens, Venus, and Castle Lakes. In 1982 the percentage of phytoflagellates and Chlorochromonas sp., so prevalent during 1981, had decreased substantially. 
By late August 1981 the bluegreen algae that had dominated Spirit Lake since late 1980 declined and the green and yellowgreen algae including the diatoms became more prevalent. The community composition in Castle Lake differed from that in Coldwater Lake throughout most of the study, particularly in 1982 when Castle Lake was dominated by diatoms and Coldwater Lake by green and bluegreen algae.

A diversity index is one way of describing the make up of a biological community. It is a summation of two properties of the community: the number of different kinds of organisms (in this case, species) present and the relative abundances of individuals among the species (Keith V. Slack, U. S. Geological Survey, written commun., 1982). Because the index is a summation, a collection with few species and an even distribution of abundance could have the same diversity as a collection with many species and an uneven distribution of abundance. The evenness component (E) provides information about the uniformity of the distribution of individuals among the species in the sample. $E=1$ describes maximum diversity where individuals are equally distributed throughout the community. Diversity indices for the phytoplankton community in the study lakes were calculated using the Shannon equation (Wilhm, 1970; Zand, 1976), with an associated evenness component (Margalef, 1958). Shannon's equation for diversity is:

$$
H^{\prime}=3.3219\left(\log _{10} N-1 / N \sum n_{i} \log _{10} n_{i}\right)
$$

where $H^{\prime}=$ diversity,

$\mathbf{N}=$ total number of individuals of all species, and

$\mathrm{n}_{i}=$ number of individuals of the ith species.

Margalef's equation for the evenness component is:

where

$$
\begin{array}{rl}
E & E=\frac{\mathrm{H}^{\prime}}{\mathrm{H}_{\max }} \\
\mathrm{H}^{\prime} & =\begin{array}{l}
\text { evenness, } \\
\mathrm{H}_{\max }
\end{array}=\begin{array}{l}
\text { diversity, } \\
\text { of species. }
\end{array}
\end{array}
$$

Average indices for July and August (table 6) showed greater species diversity in summer 1982 than in summer 1981 in samples from spirit, St. Helens, Venus, and Coldwater Lakes. The average diversity in Deadmans Lake was 2.4 in summer 1982 compared to 2.5 in summer 1981; in Castle Lake, there was virtually no change in average diversity. Of all the study lakes during 1981 the smallest diversity (0.4) and evenness component (0.1) was in Deadmans Lake in September. The next smallest diversity was 1.0 with evenness of 0.5 and 1.0 in Coldwater Lake in June and September. In 1981, the greatest diversity was 2.8 with evenness of 0.9 in Castle Lake in September; in 1982, it was 3.4 with evenness of 0.9 in St. Helens Lake in July. 


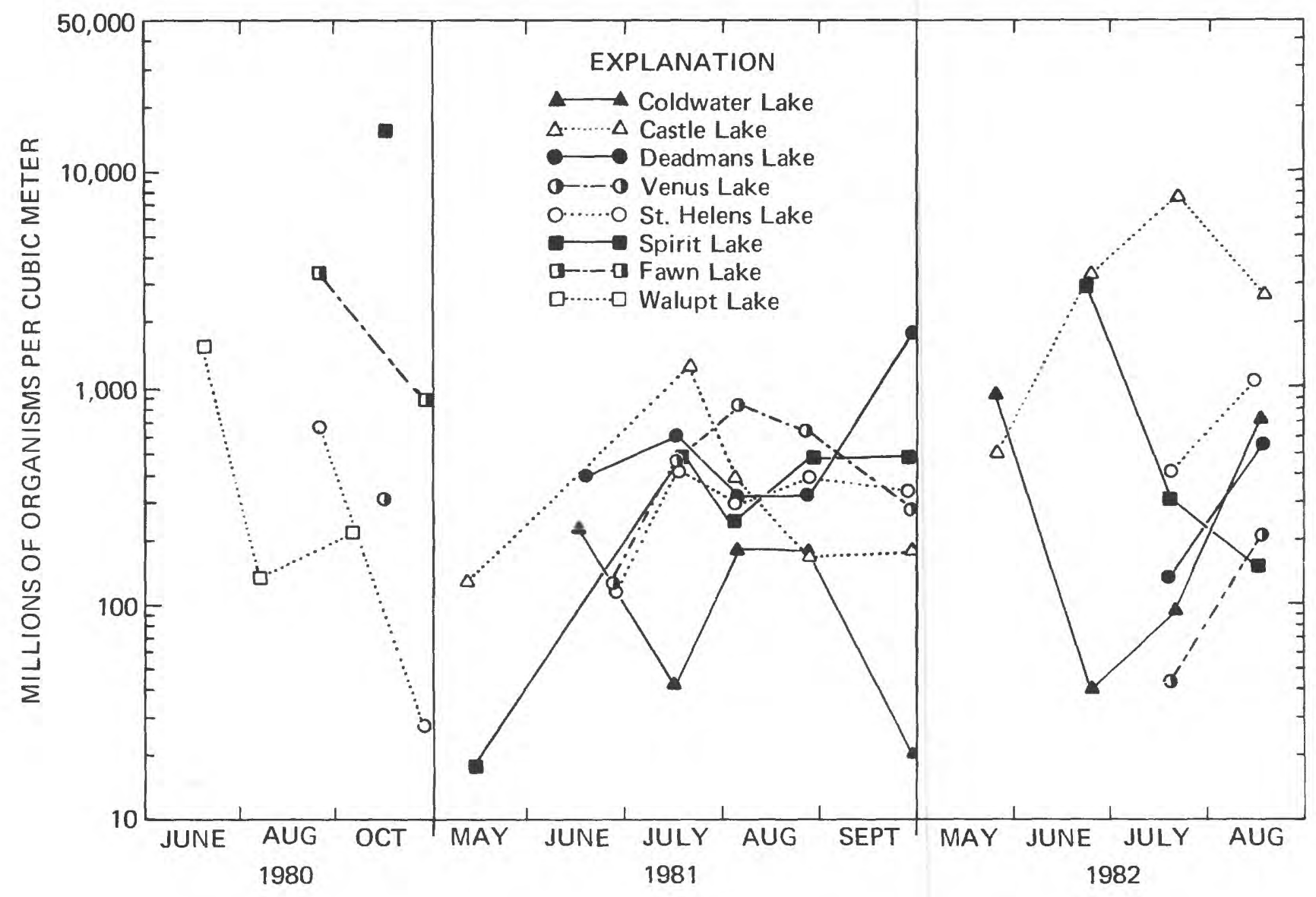

Figure 11.--Phytoplankton concentrations in the study lakes near Mount St. Helens, Washington, June 1980 to August 1982. 

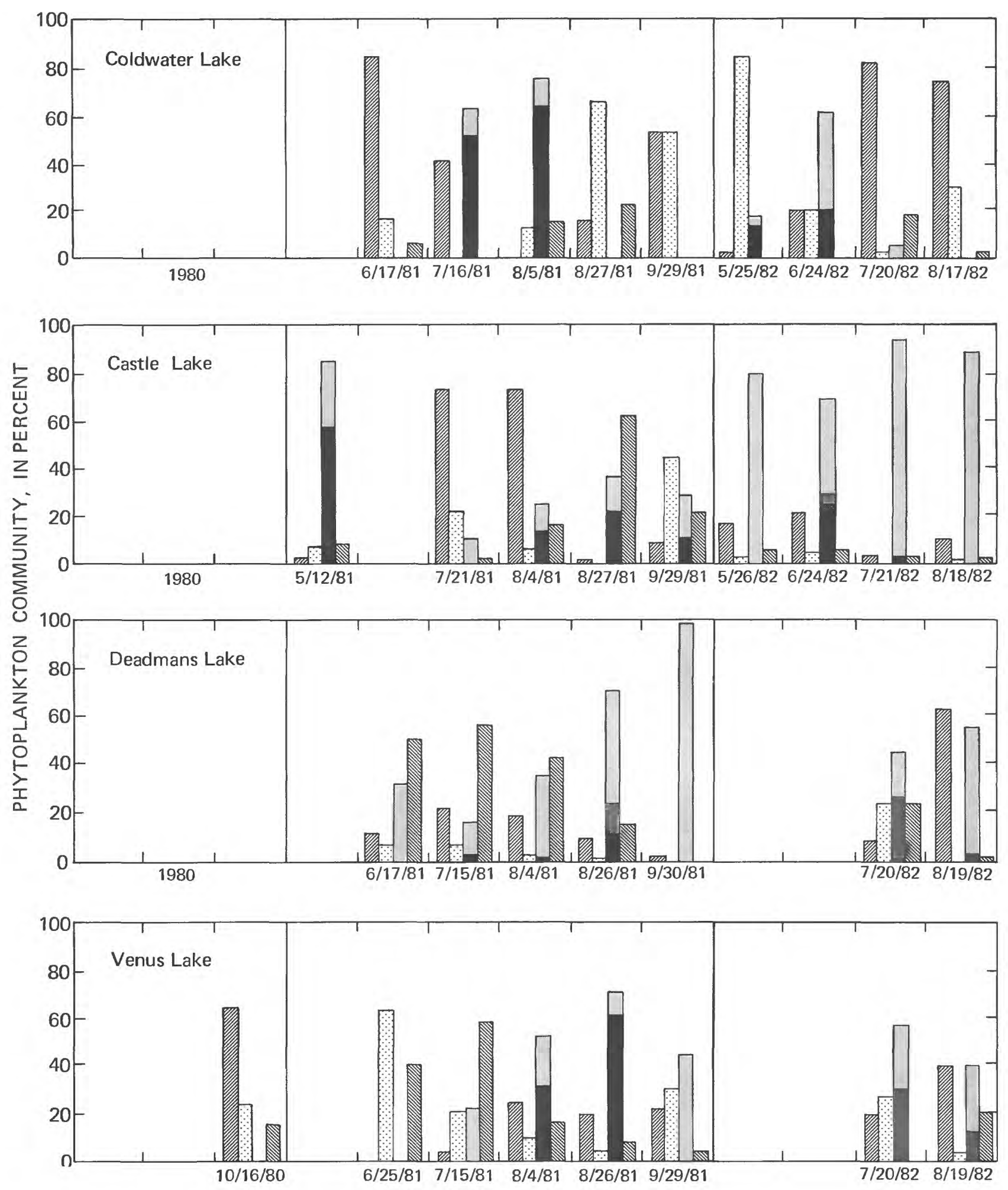

Figure 12.--Percentage composition of phytoplankton communities in the study lakes near Mount St. Helens, Washington, June 1980 to August 1982. 

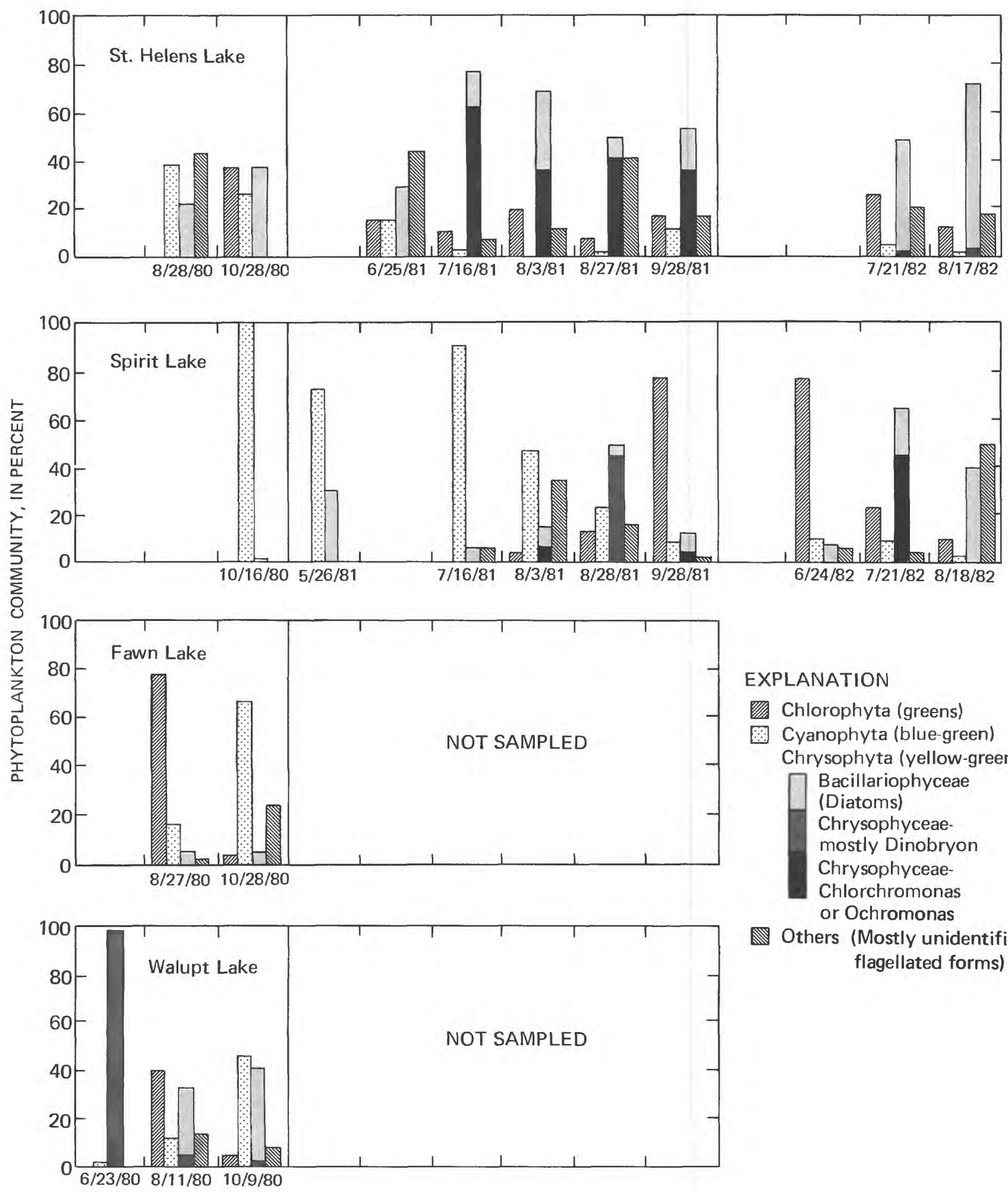

\section{EXPLANATION}

Chlorophyta (greens)

0 Cyanophyta (blue-green)

Chrysophyta (yellow-green)
Bacillariophyceae
(Diatoms)
Chrysophyceae- mostly Dinobryon
Chrysophyceae-
Chlorchromonas or Ochromonas

Others (Mostly unidentified flagellated forms)

Figure 12.--Percentage composition of phytoplankton communities in the study lakes near Mount St. Helens, Washington, June 1980 to August 1982 - - continued. 


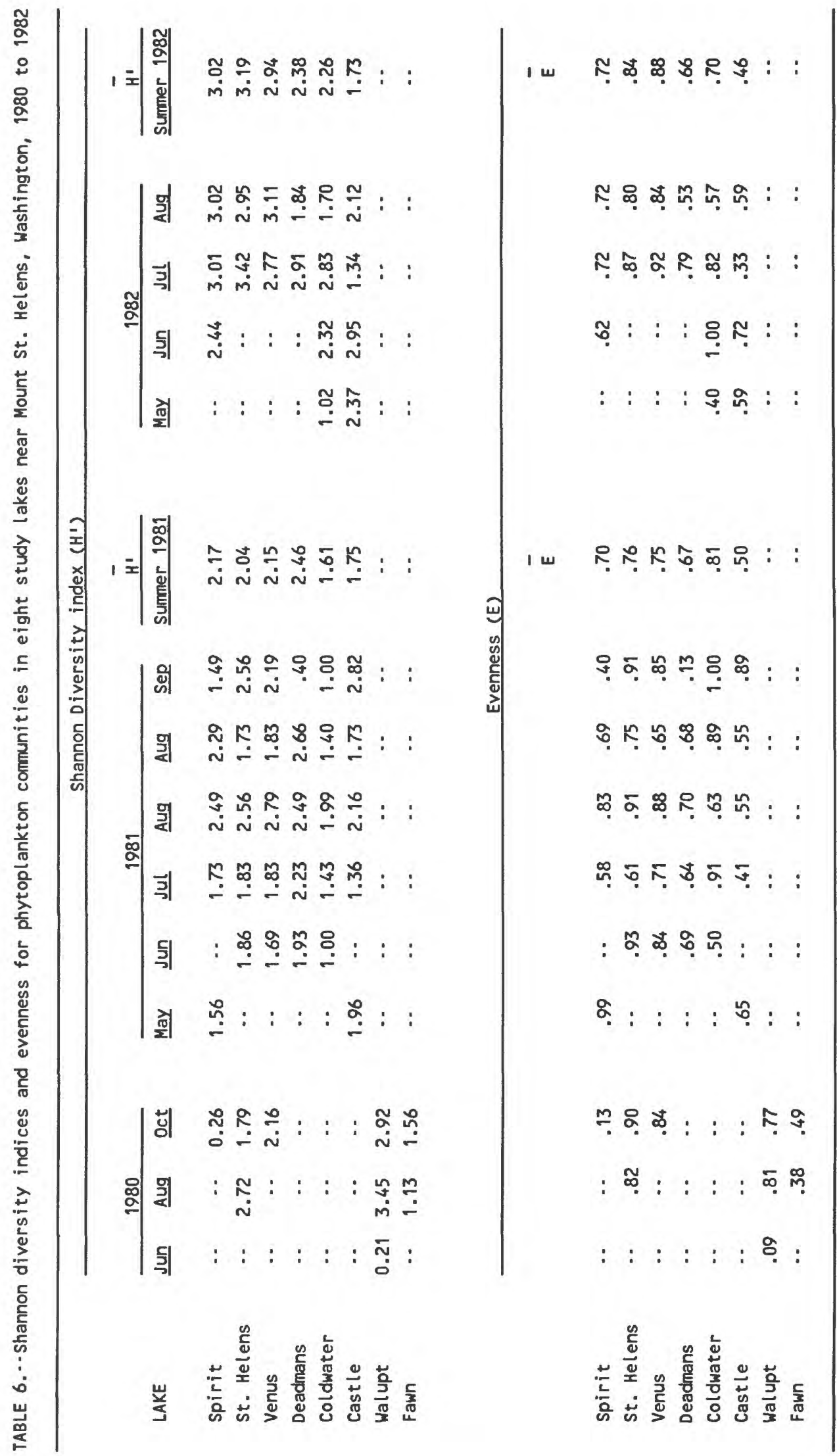




\section{Zooplankton}

Zooplankton communities measured in August and October 1980 in Spirit, St. Helens, and Venus Lakes (fig. 13) were more than 100 times smaller than the community in Walupt Lake and 1,000 times smaller than that in Fawn Lake. The smaller numbers may indicate some mortality during the eruption in lakes close to the volcano. During the period of study, however, zpoplankton concentrations increased markedly in Spirit Lake from 7 org/m in May 1981 to about $12,000 \mathrm{org} / \mathrm{m}^{3}$. Of all the study 1 gkes, St. Helens Lake generally had the smallest numbers, less than $30 \mathrm{org} / \mathrm{m}^{3}$ in 1981 and $70 \mathrm{org} / \mathrm{m}^{3}$ in 1982 , even though phytoplankton numbers in that lake were about the same as in the other lakes. Zooplankton concentrations were greater in Castle Lake than in Coldwater Lake during 1981 (except in September); however, from May to July 1982, the concentrations were greater in Coldwater Lake than in Castle Lake.

The composition of the zooplankton communities (fig. 14) in the study lakes was mainly of the phylum rotifera and the phylum arthropoda, in which two orders of the class crustacea--copepoda and cladocera--were commonly observed in the samples. The fourth category (others) of zooplankton communities shown in figure 14 includes miscellaneous types of organisms, particularly the protozoan Vorticella sp. and insects. The dominant species for each sample are indicated in the taxonomic tables of appendix $B$. All the identified species of crustacea and rotifera in the study lakes are common to the limnetic or open-water zone of a lake. Most of the species identified may be found in nearly all parts of the world and may not represent any particular trophic status or quality of water except possibly water temperature. Holopedium gibberum, a cladoceran described by Pennak as a cold stenotherm (1978, p. 363), was found in samples from Deadmans and St. Helens Lakes taken in late summer and fall, and was the dominant species in Venus Lake during late summer and early fall. A stenotherm is an organism capable of existing only within narrow limits of temperature change, and in this case, the temperatures are relatively cold. Daphnia middendorffiana, found in Castle, Coldwater, and St. Helens Lakes, is also associated mainly with cold water (Hutchinson, 1967).

In general, community compositions of zooplankton in the lakes varied in samples collected during each sampling period and may reflect changes in the dominant species or groups because of seasonal succession or food supply. The dominant group of the community in Deadmans Lake, rotifera, did not change in 1981 or 1982. Although the composition in Coldwater Lake varied during 1981 , it was dominated by the cladocera during the entire 1982 sampling season. 


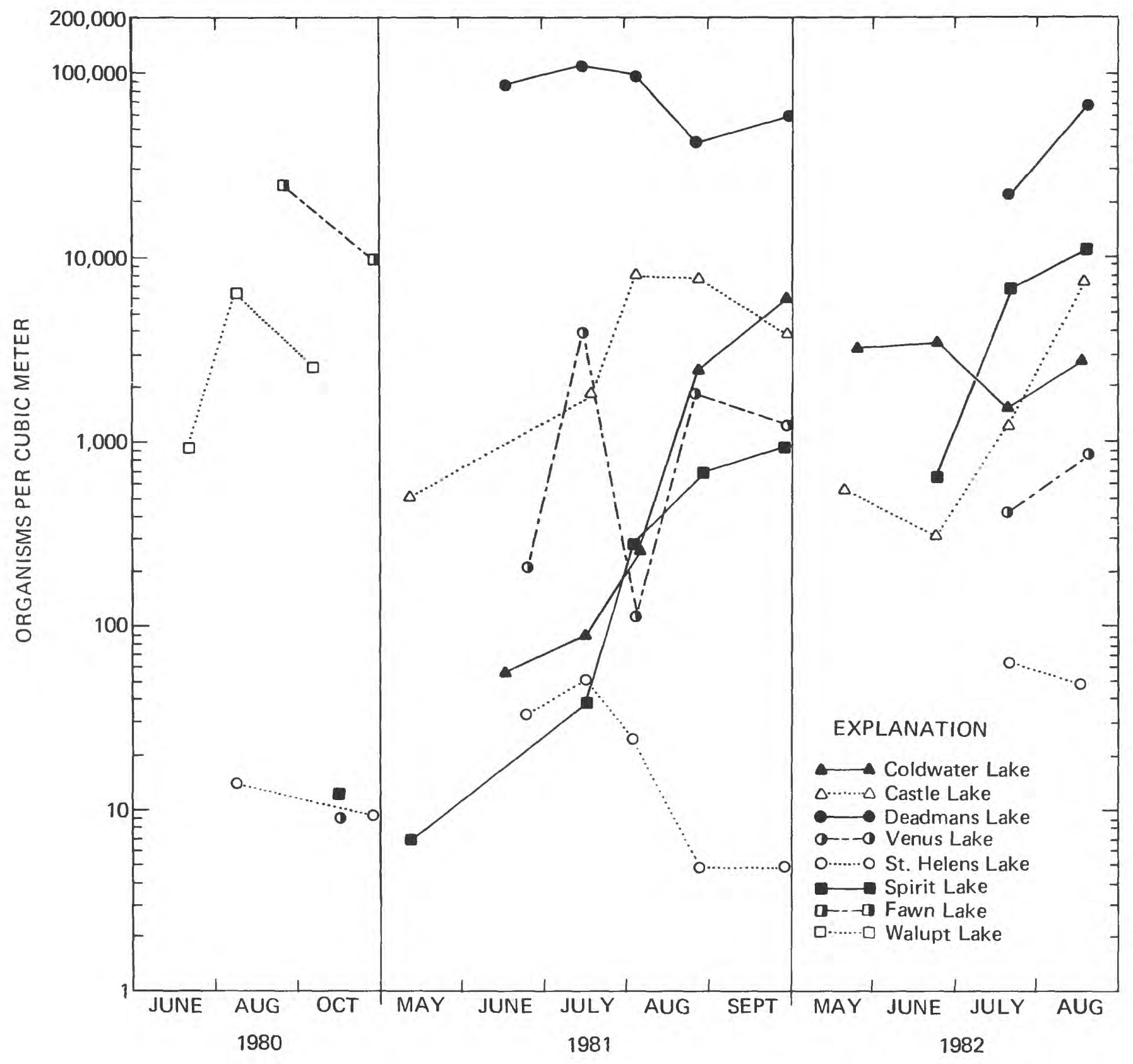

Figure 13.--Zooplankton concentrations in the study lakes near Mount St. Helens, Washington, June 1980 to August 1982. 

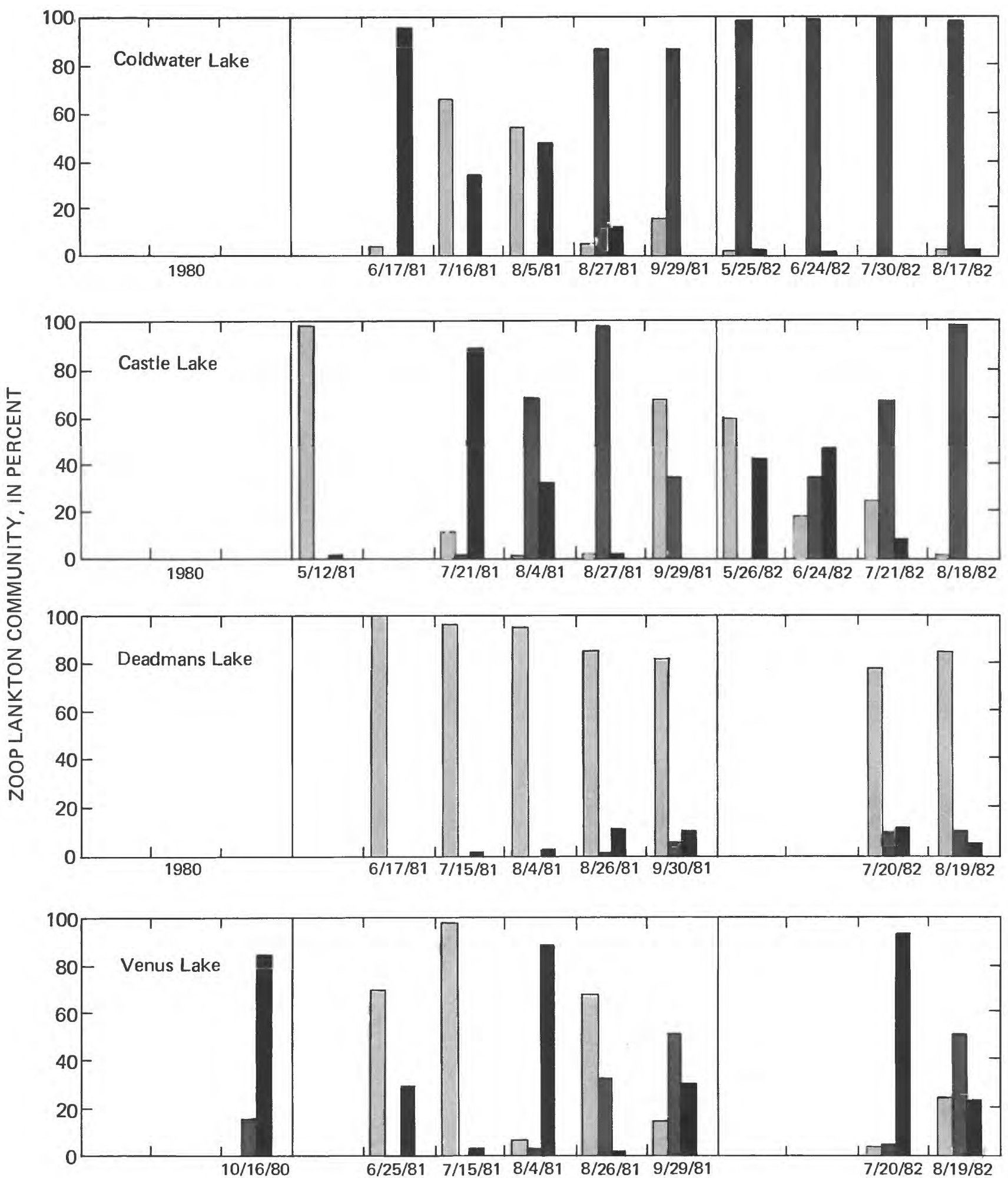

Figure 14.--Percentage composition of zooplankton communities in the study lakes near Mount St. Helens, Washington, June 1980 to August 1982. 

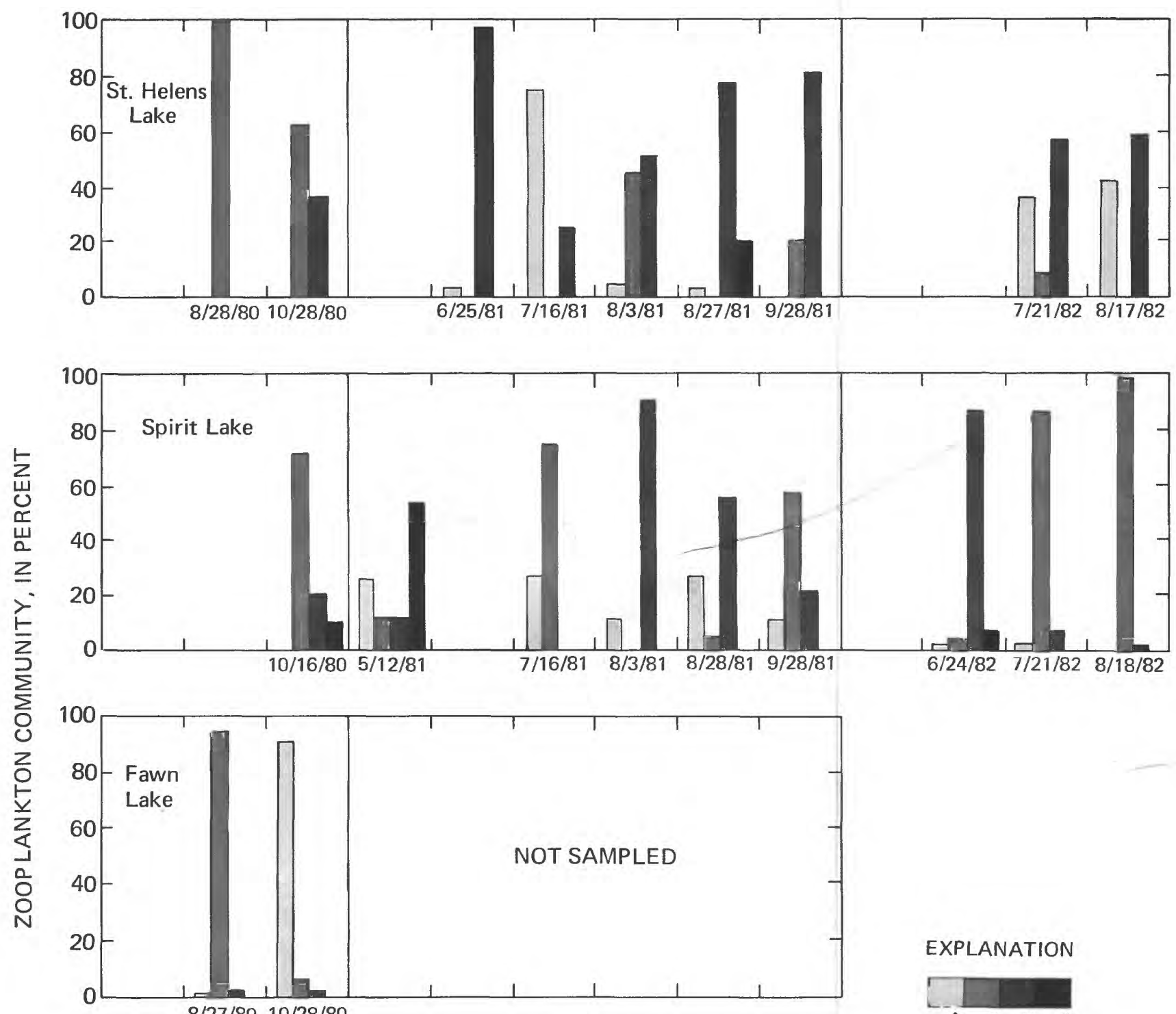

EXPLANATION

$8 / 27 / 80 \quad 10 / 28 / 80$
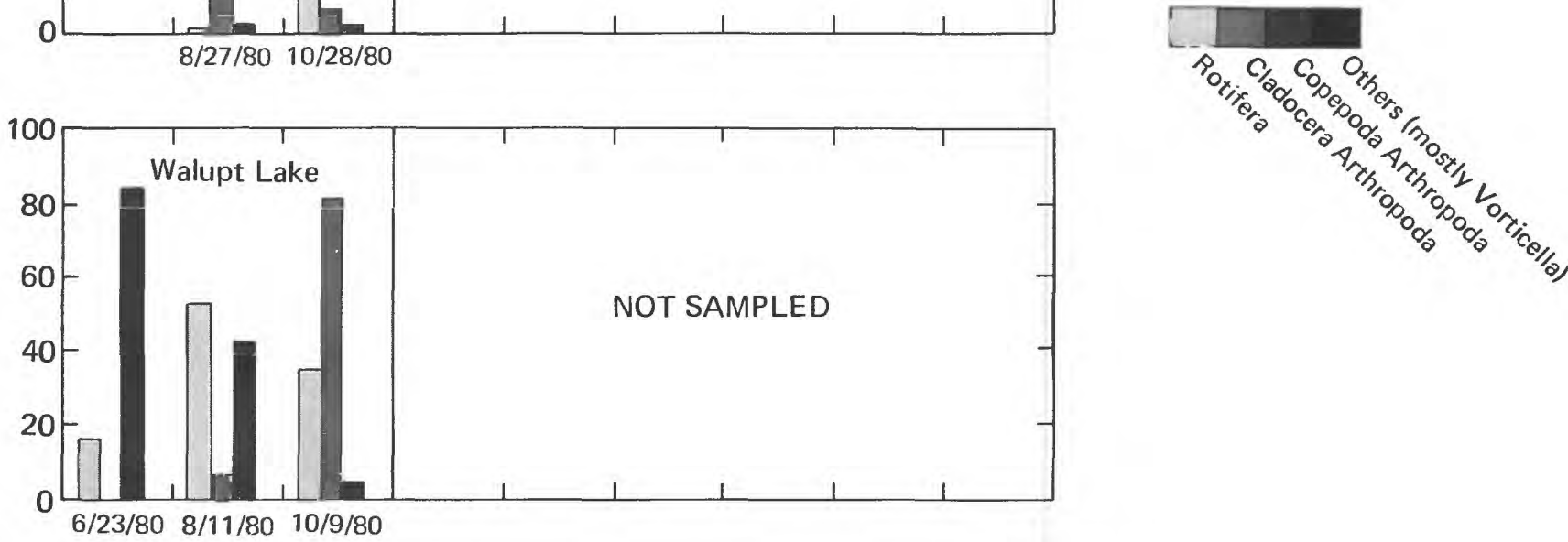

Figure 14.--Percentage composition of zooplankton communities in the study lakes near Mount St. Helens, Washington, June 1980 to August 1982 - continued. 
In 1980 the most prevalent of the four major groups of zooplankton in Spirit and St. Helens Lakes was the cladocera; in Venus Lake it was the copepoda. Rotifers were found only in Fawn and Walupt Lakes, but by 1981 they were present in all the study lakes and were occasionally dominant in Venus Lake. The zooplankton community of Spirit Lake was generally dominated by cladocera or copepoda during 1981 and 1982. In 1981, the percentage of cladocera declined in the community of St. Helens Lake and was dominated by the copepoda through 1981 (except July) and in 1982. The zooplankton community of Deadmans Lake was consistently dominated by the rotifer Kellicottia longispina throughout the study. Coldwater Lake was dominated by rotifera in spring 1981 and copepoda in July 1981, but the dominance changed to the cladoceran Ceriodaphnia quadrangula in early August 1981 and remained this way through September 1981. The 1982 community in Coldwater Lake consisted almost exclusively of the cladoceran Daphnia pulex. This may have reflected the type and abundance of the food source in the lake; Hutchinson (1967, p. 556) indicates that green algae, which were dominant in Coldwater Lake, are particularly digestible for species of Daphnia.

\section{Higher Organisms}

Conversations with other researchers and subjective field observations made at the times of lake sampling provided limited information concerning the higher organisms. The high temperatures and low DO concentrations observed in Spirit Lake after the eruption most likely killed all fish in the lake. The effects of the eruption on fish in other blast-zone lakes was described by $B$. A. Crawford of the State of Washington Department of Game (oral commun., September 11, 1981). In autumn 1980 and spring 1981, according to Crawford, baited gill nets were set in several blast-zone lakes, including St. Helens Lake. Live fish were found in Panhandle, Fawn, Tradedollar, Hanaford, and Elk Lakes;, but not in St. Helens (fig. 1). Most of the fish were eastern brook trout, but Hanaford Lake also contained cutthroat trout and Elk Lake contained rainbow trout. The fish were generally in good condition and had been feeding on terrestrial insects and, to a lesser extent, on midge larvae and freeliving (caseless) caddisflies.

In summer 1980, live frogs and tadpoles were found along the shore of Tradedollar Lake, and in summer 1981 tadpoles were seen in Deadmans and Castle Lakes. Numerous midge and mosquito larvae were observed in the open-water zone of Spirit Lake, but closely associated with the floating logs that cover much of the surface of that lake. The logs may provide a suitable habitat for numerous organisms.

In the summer of 1982, either the insect water boatman (family Corixidae) or backswimmer (family Notonectidae) was observed along the littoral zones of both Castle and Spirit Lakes. Caddisfly larvae and other insects were numerous in the man-made outlet draining Castle Lake. 


\section{PROJECTED RECOVERY OF STUDY LAKES}

The time needed for the study lakes to return to similar preeruption conditions will be controlled mostly by stabilization of the volcano and the lake watersheds, and the biological processes taking place within each lake. Specific estimates of recovery time for each study lake were not possible given the limited amount of data collected in this relatively short study.

Recovery will also depend on the rate of dilution and the water-exchange time for a given lake. Water-exchange time is the period of time that the water volume of a lake would be replaced by an equal volume of water inflow. Exchange time was estimated in this study by relating lake volume with area precipitation and evaporation losses from the lake's water surface and the drainage-basin area (see table 1), using the following equation:

$$
\text { exchange (years) }=\frac{L V}{P-(E T+L E)}
$$

where $L V=$ lake volume, in acre-feet,

$\mathrm{P}=$ mean annual precipitation over the drainage-basin area, in acre-feet,

$\mathrm{ET}=$ mean annual evapotranspiration for the drainage-basin area less the lake-surface area, in acre-feet, and

$\mathrm{LE}=$ mean annual lake evaporation over the surface of the lake, in acre-feet.

Mean annual precipitation ranging from 80 to 105 inches per year was estimated from map M-4430 (U. S. Weather Bureau, 1965); estimated mean annual

evapotranspiration was 20 inches (U. S. Weather Bureau maps, 1962); and lakesurface evaporation was 24 inches per year (Kohler and others, 1959). Mean annual values of precipitation, evapotranspiration, and lake-surface evaporation were multiplied by the corresponding areas and converted to units of acre-feet for use in the exchange equation.

An exchange time for Spirit Lake was not estimated because of the lack of a permanent outlet, the quantity of avalanche and volcanic debris in the lake, the extraordinary $\log$ cover, and the threat of future mud and pyroclastic flows into the lake. The estimated exchange time for St. Helens Lake is 5.4 years, and for Venus Lake 1.3 years (see table 1). Based on severity of effects and estimated exchange times, Venus Lake appears likely to recover the fastest of the study lakes and St. Helens the slowest. It may be decades before St. Helens Lake returns to near preeruption conditions. 
This report discusses the effects of the May 18, 1980, eruption of Mount St. Helens on the limnological characteristics of four selected lakes within the blast zone of the volcano (Spirit, St. Helens, Venus, and Fawn), and two lakes outside of the blast zone (Deadmans and Walupt). The limnology of two newly created lakes (Coldwater and Castle), formed by the deposition of debris in the upper North Fork Toutle River valley, is also included in the report. Data collection began in June 1980 and ended in August 1982, and included measurements of physical, chemical, and biological characteristics.

All the existing study lakes received varying quantities of volcanic ash and organic debris. In addition, Spirit Lake received pyroclastic flow and avalanche material that elevated the lake's surface by about 230 feet and increased its area by about 900 acres. The most apparent effects observed during summer 1980 immediately after the eruption were physical in nature. Light transmission through the water column was reduced and two types of optical conditions were observed: severe turbidity from suspended particulate matter, as typified by St. Helens Lake, and intense color from staining by dissolved-organic debris, as in Spirit and Castle Lakes. Water transparency and color had improved in all lakes by August 1982; Venus Lake showed the most improvement and St. Helens Lake the least.

Although the water in Spirit Lake had been heated to more than $32^{\circ} \mathrm{C}$ during the eruption, the surface temperature had decreased to near preeruption levels $\left(13^{\circ} \mathrm{C}\right)$ by October 1980 .

In general, dissolved-oxygen (DO) profiles during thermal stratification in lakes in the blast zone were altered from a positive, heterograde curve to a clinograde curve. The new lakes, Castle and Coldwater Lakes, also developed clinograde DO curves during summers 1981 and 1982. The change in curve shape, characterized by the absence of DO in the hypolimnion, may be due in part to reduced photosynthesis rates, and to the introduction of increased amounts of chemically reduced materials in the lakes. Deadmans Lake retained a

heterograde curve throughout the study. Spirit Lake was virtually devoid of DO into fall 1980, but by May 1981 the lake DO concentrations were 5.2 and 3.2 $\mathrm{mg} / \mathrm{L}$ near the surface and bottom, respectively.

Water samples taken in June 1980 from Spirit, St. Helens, and Venus Lakes showed increased concentrations of total and dissolved organic and inorganic constituents. As a result of the eruption, dissolved solids in the study lakes increased by 2 to 30 times preeruption concentrations measured during 1971 and 1974 studies. Increases in concentrations of many constituents in Spirit, St. Helens, Venus, and Fawn Lakes were less as the distance from the volcano increased. The water type in the study lakes, assumed to have previously been a calcium-bicarbonate type, shifted to calcium-sulfate, calcium-sulfate-chloride, or mixed type in all of the lakes except Walupt. Castle Lake formed as a calcium-bicarbonate type and remained so during the study; however, Coldwater Lake formed with a mixed water type. The shift of major-ion compositions in the water chemistry of the lakes was probably caused by water-soluble salts of chloride and sulfate condensed on the surfaces of ash particles, as suggested by other investigators. 
Preeruption nutrient levels were naturally small and primary production was probably limited first by the amount of phosphorus available and then by nitrogen. After the eruption, the lakes were enriched to some extent in inorganic phosphorus, which declined by 1981 to about $0.05 \mathrm{mg} / \mathrm{L}$ in Spirit Lake and less in the other lakes. The algae probably were limited more by reduced light, increased trace metal concentrations, and bacterial competition than by small nutrient levels. As the lakes recover, nutrient concentrations probably will again be the first limiting factors to algal primary production.

Concentrations of total organic carbon in Spirit Lake increased about 20 times over preeruption concentrations, and doubled in Venus, Fawn, and St. Helens Lakes. The major source of the organic materlals is assumed to be from the pyrolization of the coniferous forest that surrounded the volcano prior to eruption. Concentrations of iron and manganese were substantially increased over preeruption levels, particularly in Spirit Lake. The anoxic conditions in the hypolimnia of the blast-zone lakes mobilized high concentrations of iron and manganese.

Because of the lack of preeruption data for the study lakes, changes in the biology that may have occurred as a result of the eruption can only be surmised. It is assumed that little, if any, of the aquatic life present in Spirit Lake before May 18, 1980, survived the effects of the eruption. By October 1980 a dense population of Rhabdoderma lineare (a bluegreen algal species), numbering 15,000 million organisms per cubic meter, had developed in Spirit Lake. This population was not present in such large numbers either in 1981 or 1982 .

of all the study lakes, newly created Castle Lake had the largest phytoplankton blomass (as approximated by chlorophyll a concentrations). Average summer chlorophy11 a in Castle Lake was $6.6 \mu \mathrm{g} / \mathrm{L}$ by 1982; average summer concentrations in the other five lakes were less than $4.0 \mu \mathrm{g} / \mathrm{L}$. On the basis of concentrations of chlorophyll a, all lakes except Castle Lake were oligotrophic; Castle Lake was mesotrophic.

Phytoplankton concentrations in Castle Lake were higher during 1982 than during 1981 and were generally higher than concentrations in the other lakes. Despite the low light transmission in St. Helens Lake, the concentrations of algae during 1981 and 1982, ranging from 110 to 1,090 million organisms per cubic meter, were not substantially different from the other lakes. The phytoplankton communities in the existing blast-zone lakes in late summer 1980 were composed primarily of green and bluegreen algae. During most of summer 1981, the phyto-flagellates were the most numerous forms identified in most of the lakes. Diatoms were relatively unimportant in all the blast-zone lakes, existing and new, until summer 1982 .

After the eruption, concentrations of zooplankton in Spirit, St. Helens, and Venus Lakes were more than 100 times less than populations in Walupt Lake and 1,000 times less than those in Fawn Lake. This may indicate some degree of mortality during the eruption in lakes close to the volcano. The total number of zooplankton increased from 7 to about 12,000 organisms per cubic meter in Spirit Lake between May 1981 and August 1982. Of all the lakes, Deadmans Lake had the largest concentrations ranging from about 23,000 to 111,000 organisms per cubic meter, of zooplankton in 1981 and 1982; St. Helens Lake generally had the smallest (less than 70 organisms per cubic meter). By 
summer 1982, zooplankton concentrations in Coldwater Lake were higher than in Castle Lake. Community compositions within the lakes were variable and may reflect changes due to season or food supply. The zooplankton population in Deadmans Lake was continuously dominated by the rotifer Kellicottia longispina during the study. Rotifers were absent from all study lakes in the blast zone except Fawn Lake in 1980, but were present in all the lakes by 1981. Most zooplankton species identified in the study lakes may be found in nearly all parts of the world.

The time required for the recovery of the lakes to preeruption conditions depends on the degree of stabilization of the volcano and lake watersheds, on the biological processes within the lakes, and the rates of dilution and water exchange for each lake. Information from this study suggests that, excluding Spirit Lake, St. Helens Lake will recover the slowest and Venus Lake the fastest. An estimate of recovery time for Spirit Lake was not possible because of the extraordinary quantity of debris added to the basin and the threat of future mud and pyroclastic flows into the lake. 
American Public Health Association, and others, 1980, Standard methods for the examination of water and wastewater, 15 ed.: New York, American Public Health Association, Inc., $1134 \mathrm{p}$.

Bortleson, G. C., Dion, N. P., McConne11, J. B., and Nelson, L. M., 1976, Reconnaissance data on lakes in Washington, volume 4: Washington Department of Ecology Water-Supply Bulletin 43, v. 4, 197 p.

Bortleson, G. C., Higgins, G. T., and Hill, G. W., 1974, Data on selected lakes in Washington, part 2: Washington Department of Ecology WaterSupply Bulletin 42, part 2, 145 p.

Collings, M. R., 1973, Data on selected lakes in Washington, part I: U.S. Geological Survey Open-File Report, 179 p.

Dahm, C. N., Baross, J. A., Ward, A. K., Lilley, M. D., and Sedel1, J. R., 1983, Initial effects of the Mount St. Helens eruption on nitrogen cycle and related chemical processes in Ryan Lake: Applied and Environmental Microbiology, v. 45, no. 5, p. 1633-1645.

Dion, N. P., Bortleson, G. C., McConne11, J. B., and Innes, J. K., 1976, Data on selected lakes in Washington, part 5: Washington Department of Ecology Water-Supp1y Bulletin 42, part 5, 125 p.

Dion, N. P., and Embrey, S. S., 1981, Effects of Mount St. Helens eruption on selected lakes in Washington: U.S. Geological Survey Circular 850-G, $25 \mathrm{p}$.

Foxworthy, B. L., and H111, Mary, 1982, Volcanic eruptions of 1980 at Mount St. Helens--the first 100 days: U.S. Geological Survey Professional Paper $1249,125 \mathrm{p}$.

Hutchinson, G. E., 1967, A treatise on limnology: vol II--Introduction to lake biology and the limnoplankton: New York, John Wiley and Sons, Inc., 1115 p.

Kohler, M. A., Nordenson, T. J., and Fox, W. E., 1959, Evaporation map for the United States: U.S. Department of Commerce Weather Bureau Technical Paper 37, 13 p., 5 plates.

Margalef, D. R., 1958, Information theory in ecology: General Systems, v. 3, no. 36 .

Meyer, William, and Carpenter, P. J., 1983, Filling of Spirit Lake, Washington, May 18, 1980, to July 31, 1982: U.S. Geological Survey OpenFile Report 82-771, 19 p.

McKnight, D. M., Pereira, W. E., and Ceazan, M. L., 1982, Characterization of dissolved organic materials in surface water within the blast zone of Mount St. Helens, Washington: Organic Geochemistry, v. 4, p. 85-92. 
Pennak, R. W., 1953, Fresh-water invertebrates of the United States: New York, Ronald Press Co., 770 p.

1978, Fresh-water invertebrates of the United States (2nd ed.): New York, John Wiley and Sons, 803 p.

Pereira, W. E., Rostad, C. E., Taylor, H. E., and Klein, J. M., 1982, Characterization of organic contaminants in environmental samples associated with Mount St. Helens 1980 volcanic eruption: Environmental Sclence and Technology, v. 16, no. 7, pp. 387-396.

Prescott, G. W., 1962, Algae of the western Great Lakes area: Dubuque Iowa, Wm. C. Brown Co., 977 p. 1970, The freshwater algae: Dubuque, Iowa, Wm. C. Brown Co., 348 p. 1978, How to know the freshwater algae, third edition: Dubuque, Iowa, Wm. C. Brown Co., 293 p.

Sarna-Wojcicki, A. M., Shipley, Susan, Waltt, R. B., Dzurisin, Daniel, Hayes, W. H., Davis, J. O., Wood, S. H., and Bateridge, Thomas, 1980, Aerial distribution, thickness, and volume of downwind ash from the May 18, 1980, eruption of Mount St. Helens: U.S. Geological Survey OpenFile Report 8-1078, 14 p.

Skougstad, M.W., Fishman, J. J., Friedman, L. C., Erdmann, D. E., and Duncan S. S., editors, 1979, Methods for determination of inorganic substances in water and fluvial sediments: U.S. Geological Survey Techniques of Water-Resources Investigations, Book 5, chap. Al, 626 p.

Taylor, H. E., and Lichte, F. E., 1980, Chemical composition of Mount St. Helens ash: Geophysical Research Letters, v. 7, no. 11, p. 949-953.

U.S. Weather Bureau, 1965, Mean annual precipitation, 1930-57, State of Washington: Portland, Oregon., U.S. Soll Conservation Service, map M-4430.

U.S. Weather Bureau, and U.S. Department of Agriculture, Soil Conservation Service, 1962, Evapotranspiration maps for the state of Washington: unbound, unpaged.

Waitt, Jr., R. B., and Dzurisin, Daniel, 1981, Proximal air-fall deposits from the May 18 eruption, p. 601-616 in Lipman, P. W., and Mullineaux, D. R., editors, The 1980 eruptions of Mount St. Helens, Washington: U.S. Geological Survey Professional Paper 1250, 844 p.

Ward, H. B., and Whipple, G. C., 1959, Fresh-water biology (2nd ed.): New York, John Wiley and Sons, Inc., 1248 p.

Welch, E. B., 1980, Ecological effects of wastewater, New York, Cambridge University press, $337 \mathrm{p}$. 
Welch, P. S., 1948, Limnological methods: New York, McGraw Hill Book Company, Inc., $381 \mathrm{p}$.

Wetzel, R. G., 1975, Limnology: Philadelphia, W. B. Saunders Co., 743 p.

Wilhm, J. L., 1970, Effects of sample size in Shannon's formula: The Southwestern Naturalist, v. 44, p. 441-445.

Youd, T. L., Wilson, R. C., and Schuster, R. L., 1981, Stability of blockage in North Fork Toutle River: Mount St. Helens hazards investigations: in Lipman, P. W., and Mullineaux, D. L., editors, The 1980 eruptions of Mount St. Helens, Washington: U.S. Geological Survey Professional Paper 1250 , p. $821-828$.

Zand, S. M., 1976, Indexes associated with information theory in water quality: Journal Water Pollution Control Federation, v. 48, no. 8 , p. 2026-1031. 
[ O Dominant or co-dominant]

\begin{tabular}{|c|c|c|c|c|c|c|c|c|c|}
\hline PHYTOPLANKTON & $6 / 17 / 81$ & $7 / 16 / 81$ & $8 / 05 / 81$ & $\underline{8 / 27 / 81}$ & $9 / 29 / 81$ & $5 / 25 / 82$ & $6 / 24 / 82$ & $7 / 20 / 82$ & $8 / 17 / 82$ \\
\hline \multicolumn{10}{|l|}{ Chlorophyta } \\
\hline \multicolumn{10}{|l|}{ Chlorophyceae } \\
\hline Ankistrodesmus falcatus G.M. Smith & (X) & (X) & -- & $\mathrm{x}$ & -- & - & -- & -- & -- \\
\hline$\frac{\text { Ankistrodesmus falcatus }}{\text { (West \& West) G.S. West }}$ & - & - & -- & -- & $\mathrm{x}$ & -- & -- & - & -- \\
\hline$\frac{\text { Ankistrodesmus falcatus }}{\text { West \& West }}$ tumidus & -- & - & -- & -- & -- & -- & -- & -- & (8) \\
\hline Crucigenia quadrata Morren & -- & -- & -- & -- & -- & -- & -- & -- & $x$ \\
\hline Dictyosphaerium pulchellum Wood & -- & -- & -- & -- & -- & -- & - & (x) & (X) \\
\hline Golenkinia paucispina West \& West & - & -- & -- & -- & -- & -- & $x$ & (x) & -- \\
\hline Docystis sp. Snow & -- & -- & -- & -- & -- & -- & -- & - & $x$ \\
\hline Oocystis Borgei Snow & -- & -- & -- & -- & -- & $\mathrm{x}$ & -- & $\mathrm{x}$ & - \\
\hline Unidentified & -- & -- & -- & -- & -- & -- & -- & $x$ & -- \\
\hline \multicolumn{10}{|l|}{ Chrysophyta } \\
\hline \multicolumn{10}{|l|}{ Bacillariophyceae } \\
\hline Achnanthes lanceolata (Breb.) Grun. & -- & $\mathrm{x}$ & -- & -- & -- & -- & -- & -- & -- \\
\hline Achnanthes $\underline{\text { Linearis }}$ & -- & -- & -- & -- & -- & -- & $x$ & -- & - \\
\hline Achnanthes minutissima & -- & -- & -- & -- & -- & -- & -- & $x$ & $x$ \\
\hline Cyclotella sp. Kutz. & -- & -- & $\mathrm{x}$ & -- & -- & $x$ & $x$ & - & -- \\
\hline Cyclotella pseudostelligera & -- & -- & $\mathrm{x}$ & -- & -- & -- & -- & -- & -- \\
\hline Cymbella sp. Agardh & -- & -- & -- & -- & -- & $x$ & -- & -- & -- \\
\hline Nitzschia sp. Hassal & -- & -- & -- & -- & -- & -- & -- & $x$ & -- \\
\hline Nitzschia palea & -- & -- & $x$ & -- & -- & -- & - & -- & -- \\
\hline ChLorochromonas sp. Lewis & -- & (X) & (X) & -- & -- & $x$ & $x$ & -- & -- \\
\hline (Ochromonas sp. Wystozki) & & & & & & & & & \\
\hline Unidentified & -- & -- & -- & -. & -- & -- & -- & $\mathrm{x}$ & -- \\
\hline \multicolumn{10}{|l|}{ Cyanophyta } \\
\hline \multicolumn{10}{|l|}{ Cyanophyceae } \\
\hline Anabaena sp. Bory & -- & -- & $x$ & -- & -- & -- & -- & -- & -- \\
\hline$\frac{\text { Anabaena ineequelis }}{\text { Bornet \& Flahault }}$ & -- & -- & -- & (X) & -- & -- & -- & -- & -- \\
\hline Chroococcus sp. Naegeli & $\mathrm{x}$ & -- & -- & -- & -- & -- & -- & -- & -- \\
\hline Chroococcus dispersus (Keissl.) Lerm. & - & - & -- & -- & -- & (X) & $\mathrm{x}$ & -- & $x$ \\
\hline Dactylococcopsis sp. (Reinsch) Hansgirg & -- & -- & -- & -- & -- & - & -- & -- & $x$ \\
\hline Dactylococcopsis fascicularis Lemmermann & -- & -- & $x$ & -- & -- & -- & -- & -- & -- \\
\hline \multicolumn{10}{|l|}{ Rhabdoderma Iineere Schmidle \& } \\
\hline Lauterborn in Schmidle & -- & -- & - & -- & $\mathrm{x}$ & $\mathrm{x}$ & -- & -- & -- \\
\hline Lyngbya sp. Agardh & -- & -- & -- & -- & -- & -- & -- & $x$ & -- \\
\hline Unidentified & $\mathrm{x}$ & -- & $x$ & -- & -- & -- & -- & - & -- \\
\hline \multicolumn{10}{|l|}{ Cryptophyta } \\
\hline Unidentified & -- & -- & -- & -- & -- & -- & -- & -- & $\mathrm{x}$ \\
\hline \multicolumn{10}{|l|}{ Euglenophyta } \\
\hline \multicolumn{10}{|l|}{ Euglenophyceae } \\
\hline EugLena sp. Ehrenberg & -- & -- & -- & -- & -- & -- & -- & $x$ & -- \\
\hline \multicolumn{10}{|l|}{ Pyrrophyta } \\
\hline \multicolumn{10}{|l|}{ Dinophyceae } \\
\hline Peridinium inconspicuum Lemmermann & - & -- & $x$ & $x$ & -- & -- & -- & -- & -- \\
\hline Unidentified cyst & -- & -- & -- & -- & -- & -- & -- & $x$ & -- \\
\hline \multicolumn{10}{|l|}{ Other } \\
\hline Unidentified flagellates & $\mathrm{x}$ & -- & $\mathrm{x}$ & -- & -- & -- & .- & $x$ & $\mathrm{x}$ \\
\hline
\end{tabular}


[ O Dominant or co-dominant]

PHYTOPLANKTON

Chlorophyta

Chlorophyceae

Ankistrodesmus falcatus var. mirabilis (West \& West) G.S. West

Chlorella vulgaris Beyerinck

Dictyosphaerium pulchellum Wood

Gloeocystis planctonica (W. \& W.) Lemm.

Golenkinia radiata (Chod.) Wille

Nephrocytium Lunatum $W$. West

Docystis (?) sp. Naegeli in A. Braun

Oocystis parva West \& West

Schroederia setigera (Schroed.) Lerm.

Xanthtdium sp. Ehrenberg

Unidentified

Chrysophyta

Bacillartophyceae

Cocconeis sp. Ehren.

Cyclotella sp. Kutz.

Cyclotella glomerata Bachm.

Cyclotella pseudostelligera Grun.

Cyclotella stelligera (Cl. and Grun.) V.H.

Fragilaria crotonensis Kitton

Navicula sp. Bory

Nitzschia sp. Hassall

Nitzschia acicularis $\mathrm{W}$. Sm.

Nitzschia capttellata Hust.

Nitzschia dissipata (Kutz.) Grun.

Nitzschia palea (Kutz.) W. Sm.

Rhizosolenia sp. Ehr. Emend, Brightw.

Synedra minuscula Grun.

Synedra rumpens Kutz.

Unidentified pennate

Unidentified centric

Chrysophyceae

Dinobryon bavaricum Imhof

Dinobryon divergens Imhof

Chlorochromonas sp. Lewis

(Ochromonas sp. Wystozki)

Cyanophyta

Cyanophyceae

Aphanothece sp. Naegeli

Chroococcus dispersus (Keissl.) Lemmermann

Microcystis incerta Lemmermann

Rhabdoderma irregulare (Naunann) Geitler

Rhabdoderma lineare Schmidle \& Lauterborn in Schmidle

Euglenophyta

Euglenophyceae

Trachelomonas sp. Ehrenberg

Unidentified

Pyrrophyta

Dinophyceae

Glenodintum pulvisculus (Ehren.) Stein

Peridinium inconspicuum Lemmermann Unidentified

Other

Unidentified flagellates

Phycomycetes

Fung i imperfect 1

$\underline{6 / 17 / 81} \underline{7 / 16 / 81} \quad 8 / 4 / 8$

$9 / 30 / 81$

$7 / 20 / 82$

8/19/82

(1)

$\begin{array}{ll}-- & -- \\ -- & -- \\ x & \times \\ -- & -- \\ -- & -- \\ -- & -- \\ -- & -- \\ -- & -- \\ -- & -- \\ -- & -- \\ x & x\end{array}$

$\mathbf{x}$
--
--
--
--
--
--
$\mathrm{x}$
$\mathrm{x}$
--
--

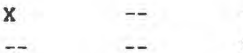

-- $\quad$-- $\quad$ X

$+-$

--

$\begin{array}{lll}- & - & - \\ - & - & -\end{array}$

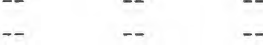

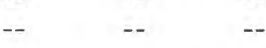

$\begin{array}{llll}-- & -- & -\end{array}$

-- $\quad-$ X

$\begin{array}{llll}-- & -- & --\end{array}$

$\begin{array}{llll}-- & -- & -\end{array}$

$\begin{array}{llll}-- & -- & -\end{array}$

$\begin{array}{lll}-- & -- & -\end{array}$

(x)

$--$

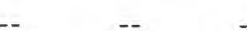

$\begin{array}{lll}-- & x & x\end{array}$

$\begin{array}{lll}- & x & x \\ - & x & -\end{array}$

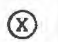

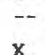

$\mathbf{x}$

(ब)

$-$

$-$

$\mathrm{x}$

$\mathrm{x}$

X

$-$

$\mathrm{x}$

$-$

(ब)

--

$x^{1}$

(ब)

-- $\quad x$

-- X

-. $\quad-$

-- $\mathrm{x}$

$--\quad--$

$\mathrm{x} \quad \mathrm{x}$

$--\quad-$

$--$

$-$

$--$

(x) $x \quad x$

-- -

-- $\quad--$

x $\quad x$

$\begin{array}{lll}-- & -- & x \\ -- & -- & \end{array}$

$x+$

$\begin{array}{lll} & -1 & - \\ -- & --\end{array}$

-- $x$ -

-- $--\quad x$

(x) $x \quad-$

x $x+-$

$\begin{array}{ll} & \\ -- & -- \\ -- & -- \\ -- & x \\ x & x \\ -- & --\end{array}$

$--$

$\times$

$\begin{array}{lllllll}-- & -- & \mathrm{x} & -- & -- & -- & - \\ -- & -- & -- & \mathrm{x} & -- & -- & -\end{array}$

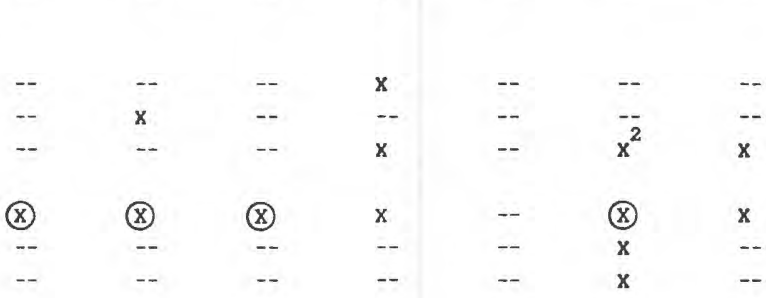


Chlorophyta

Chlorophyceae

Carteria sp. Diesing

Gloeocystis (?) sp. Naegeli

(x)

Oocystis sp. Naegeli in A. Braun

Schroederia setigera Lemmermann

$\mathrm{X}$

$--\quad x$

rysophyta

Bacillariophyceae

Achnanthes sp. Bory

Cyclotella sp. Kutz.

Nitzschia filiformis (W. Sm.) Hust.

Synedra sp. Ehrenberg

Synedra delicatissima W. Sm.

Unidentified centric

$-x^{-}$

Cyanophyta

Cyanophyceae

Chroococcus sp. Naegeli

Chroococcus dispersus (Keissl.) Lemmermann

(X)

Cryptophyta

Cryptophyceae

Cryptomonas sp. Ehrenberg

Unidentified

-- $\quad \mathrm{X}$

Euglenophyta

Unidentified

$--$

(x)

Pyrrophyta

Dinophyceae

Peridinium sp. Ehrenberg

-- $\quad x$

$\mathrm{x}$

$--$

$\mathrm{X}$

$--$ Other

Unidentified flagellates 
CASTLE

[ODominant or co-dominant]

PHYTOPLANKTON

$8 / 04 / 81 \quad 8 / 27 / 81$

$\underline{9 / 29 / 81} \quad 5 / 26 / 82$

$\underline{6 / 24 / 82}$

$7 / 21 / 82$

$\underline{8 / 18 / 82}$

Chlorophyta

Chlorophyceae

Ankistrodesmus falcatus G.M. Smith

Elakatothrix viridis (Snow) Printz

Gloeocystis gigas (Kuetz.) Lagerheim

Chlamydomonas sp. Ehrenbers

Golenkinia radiata (Chod.) Wille

Golenkinia radiata v. brevispina

Tiffany \& Ahlstrom

Kirchneriella contorta (Schmidle) Bohlin

Oocystis sp. Snow

Oocystis Borgei Snow

oocystis parva

Oocystis submarina Lageiheim

Scenedesmus dimorphus (Turp.) Kuetzing

Scenedesmus incrassatulus v. mononae G.M. Smith

Unidentified Chlamydomonad form

Unidentified coccoid form

Chrysophyta

Bacillariophyceae

Achnanthes sp. Bory

Achnanthes lanceolata (Breb) Grun.

Achnanthes lanceolata v. dubia Grun.

Achnanthes minutissima Kutz.

Cyclotella sp. Kutz.

Cyclotella pseudostelligera Grun.

Cymbella lunata $W . \mathrm{Sm}$.

Gomphonema angustatum v. productum Grun.

Gomphonema parvulum Kutz.

Nitzschia sp. Hasall

Nitzschia filiformis (W. Sm.) Hust

Nitzschia palea (Kutz.) W. Sm.

Stephanodiscus sp. Ehrenb.

Synedra sp. Ehrenb.

Synedra amphicephala Kutz. v. austriaca

Synedra fasciculata (AB.) Kutz.

Synedra incisa Boyer

Synedra nana Leist.

Synedra radians Kutz.

Synedra rumpens Kutz.

Synedra ulna (Nitz.) Ehrenb.

Unidentified pennate

\begin{tabular}{|c|c|c|c|}
\hline-- & -- & -- & -- \\
\hline -- & -- & $x$ & -- \\
\hline$\sim$ & -- & -- & -- \\
\hline-- & -- & -- & -- \\
\hline -- & -- & -- & -- \\
\hline -- & -- & -- & -- \\
\hline-- & -- & -. & -- \\
\hline-- & -- & $x$ & -- \\
\hline-- & -- & $x$ & -- \\
\hline -- & -- & -- & -- \\
\hline-- & -- & -- & -- \\
\hline-- & $x$ & -- & $x$ \\
\hline -- & $x$ & -- & -- \\
\hline- & (x) & (x) & -- \\
\hline$x$ & -- & $x$ & -- \\
\hline
\end{tabular}

$\begin{array}{lllll}x & -- & -- & -- & -- \\ -- & -- & -- & -- & -- \\ -- & x & -- & -- & -- \\ -- & -- & -- & -- & x \\ -- & -- & -- & x & -- \\ -- & -- & x & -- & -- \\ -- & -- & x & -- & -- \\ -- & -- & x & -- & -- \\ -- & x & -- & x & -- \\ -- & x & -- & x & x \\ -- & -- & x & -- & -- \\ -- & -- & -- & -- & -- \\ -- & -- & -- & -- & -- \\ -- & -- & -- & -- & -- \\ -- & -- & x & x & x\end{array}$

ג'

x

X

X-

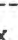

$--$

(8)

$--$

$-$

--

$-$

$-$

$--$

$-$

$-$

$-$

$-$

$-$

$-$

$$
\begin{aligned}
& x \\
& x \\
& x \\
& -- \\
& -- \\
& x \\
& \text { X } \\
& x \\
& -- \\
& x \\
& -- \\
& -- \\
& -- \\
& -- \\
& -- \\
& -- \\
& -- \\
& x \\
& \text { x } \\
& x \\
& --
\end{aligned}
$$

$\begin{array}{lll} & & \\ -- & -- & -- \\ -- & -- & -- \\ -- & -- & - \\ x & -- & x \\ x & -- & x \\ -- & -- & -- \\ -- & -- & -- \\ x & x & -- \\ -- & -- & - \\ -- & x & -- \\ -- & -- & -- \\ -- & -- & -- \\ -- & -- & \times \\ -- & -- & x \\ -- & x & -- \\ x & -- & - \\ -- & x & -- \\ -- & \times & x \\ -- & -- & - \\ \times & x & \times \\ x & -- & -- \\ -- & -- & --\end{array}$


PHYTOPLANKTON

Chrysophyceae

Dinobryon bavaricum Imhof

Dinobryon divergens Imhof

Dinobryon sertularia Ehrenb.

Dinobryon sp. (statospore) Ehrenb.

Mallomonas sp. Perty

Unidentified statospore

Chlorochromonas sp. Lewis (Ochromonas sp. Wystozki)

Cyanophyta

Cyanophyceae

Chroococcus sp. Naegeli

Chroococcus dispersus (Keiss 1.) Lemm.

Dactylococcopsis fascicularis Lem.

Lyngbya sp. Agardh

Microcystis incerta Lemmermann

Oscillatoria sp. Vaucher

Rhabdoderma irregulare (Naum.) Geit Rhabdoderma linear Schmidle \& Lauterborn in Schmidle Unidentified

Cryptophyta

Cryptophyceae

Cryptomonas sp. Ehrenb

Euglenophyta

Euglenophyceae

Phacus sp. Dujerdin

Pyrrophyta

Dinophyceae

Glenodinium sp. (Ehren.) Stein

Gymnodinium sp. (Stein) Kof. \& Swezy

Peridinium inconspicuum Lemmermann

Unidentified Other

Unidentified flagellates

Fungi imperfect 1

1 Cysts

\begin{tabular}{|c|c|c|c|c|c|c|c|}
\hline- & -- & -- & -- & -- & -- & - & $x$ \\
\hline - & -- & -- & -- & -- & -- & $x$ & $\cdots$ \\
\hline-- & -- & -- & -- & -- & - & -- & - \\
\hline-- & -- & -- & - & -- & -- & $x$ & -- \\
\hline -- & -- & -- & -- & -- & - & $x$ & - \\
\hline -- & -- & -- & -- & -- & -- & $x$ & $x$ \\
\hline (x) & -- & $x$ & (x) & $\mathrm{x}$ & $x$ & (x) & - \\
\hline
\end{tabular}

(8)

$--$

$-x$

X

$--$

-- $\quad-$

$\mathrm{x}$

$--$

--

-- $\quad \mathrm{x}$

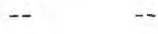

$-$

$-$

$x$

(®)

$\mathrm{x}$

x

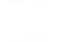

$\begin{array}{lll} & - & - \\ - & - & -\end{array}$

$\begin{array}{lllll} & - & - & - & -\end{array}$

$\begin{array}{llll}-- & -- & -- & - \\ - & x & - & -\end{array}$

$-$

$-$

$-$

$\mathrm{X}$

$-$

$+$

$-$

$--$

$\mathrm{X}$

$--$

$\begin{array}{lll}-- & -- & -- \\ -- & -- & x\end{array}$

$x$

--

$-\cdot$

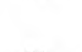

$--$

$-$

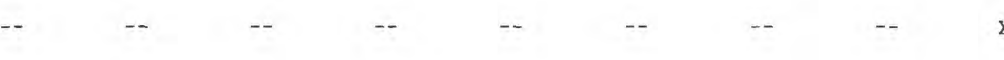

$x$

$x$

$\begin{array}{lll}-- & - \\ -- & - & x \\ -- & -- & x \\ -- & -- & -\end{array}$

$--$

-

$-$

$-$

$-$

$-$

$x^{1} \quad x^{1}$

$\begin{array}{ll}x & -- \\ x & -- \\ x & -- \\ x^{1} & x \\ & \\ x & x \\ -- & --\end{array}$

$\begin{array}{llllll}x & x & -- & x & x & x \\ -- & -- & x & -- & -\end{array}$ 
Chlorophyta

Chlorophycaee

Arikistrodesmus convolutus Corda Arkistrodesmus falcatus G.M. Smith Chlamydomonas ap. Ehrenb.

Chlamydomonas globosa Snon Chlamydomonas (?) zygote Ehranb. Kirchnerielia contorta (Schmidlo) Bohlin Kirchnerielin elongata (G.M. Soith) Kirchneriella Lunaris v. Dianae Bohlin Unidentified

Chrysophyta

Bacillariophyceae

Achnanthes minutissima Kutz.

Amphora cotfalformia (Ag.) Kutz.

Cyclotella sp. Kutz.

Cyclotella meneghiniana Kutz.

Gomphonema ensuatatum v. productum Grum.

Gomphoneme parvulum Kutz.

Melosira granulata v. angustisgima Mull.

Mitzschie sp. Basall

Nitzachla fillformis (W. Sw.) Hust.

Nitzschia tonticola Grun.

Nitzschia pales (Kutz.) W. Sm.

Synedra minuscula Grun.

Synedra rumpens Kutz.

Symedre ulne (Nitz.) Ehronb.

Chrysophyceas

Dinobryon bayarteum Imhoe

Chlorochromonas sp. Lewia

(Ochromonas sp. Wystozki)

Cyanophyte

Cyanophyceae

Anabaena sp. Bory

Anacystis ap. Meneghin

Aphanothece sp. Naegeli

Chroococcus dispersus (Kiess 1.) Lemmer.

Chroococcus ifmeticus Lemer.

Dactylococcopsis rascicularis Lemer.

Dactylococcopsis Smithil Chodat \& Chodat

Lymgbya sp. Agardh

Microcystis sp. Kuetzing

Oscillatoria sp. Vaucher

Rhabdoderma irregulara (Naumann) Geitler X

Rhabdoderma lineare Schmidle \&

Lauterborn in Schmidle

Unidentified

$\begin{array}{lllllll}-- & -- & -- & -- & - & \text { X } \\ -- & -- & -- & -- & x & -- \\ -- & -- & -- & -- & -- & - \\ -- & -- & -- & -- & -- & -- \\ -- & -- & -- & -- & - & - \\ -- & -- & -- & -- & -- & -- \\ -- & -- & -- & -- & -- & -- \\ -- & -- & -- & -- & -- & -\end{array}$

$\begin{array}{llll}-- & x & -- & -- \\ \times & x & x & x \\ -- & -- & -- & x \\ -- & x & -- & -- \\ -- & x & -- & - \\ -- & -- & x & x \\ -- & x & x & -- \\ -- & x^{2} & x & --\end{array}$

Cryptophyte

Cryptophyceas

Cryptomonas sp. Ehrenb.

Cryptomonas ovata Ehrenb.

Euglenophyta

Euglenophyceae

Trachelomonas (?) sp. Ehrenb.

Pyrrophyta

Dinophyceae

Gymodinium sp. (Stain.) Kofoid \& Swezy Unidentified flagellates

Fung1 imperfect1

Phycomycetea

$\begin{array}{llll}-- & -- & -- & - \\ -- & -- & -- & - \\ x & x & -- & - \\ -- & -- & -- & - \\ -- & -- & -- & - \\ -- & -- & -- & - \\ -- & -- & -- & - \\ -- & -- & -- & - \\ -- & -- & -- & - \\ -- & -- & -- & - \\ -- & -- & x & - \\ -- & -- & -- & - \\ -- & -- & -- & - \\ -- & -- & -- & - \\ -- & -- & - & --\end{array}$

$\begin{array}{lll}-- & x & x \\ -- & -- & - \\ -- & -- & x \\ -- & -- & - \\ -- & -- & - \\ -- & -- & - \\ -- & -- & - \\ -- & x & x \\ -- & -- & - \\ -- & -- & - \\ x & -- & x \\ -- & -- & - \\ -- & -- & - \\ -- & -- & - \\ -- & -- & x \\ x & \times & x\end{array}$

$\begin{array}{lll}-- & x & x \\ -- & -- & x \\ -- & -- & x \\ -- & -- & x \\ -- & x & - \\ x & -- & -- \\ -- & x & -- \\ x & x & x \\ -- & x & -- \\ -- & x & - \\ x & x & -- \\ -- & -- & x \\ x & x & x \\ -- & x & x \\ -- & -- & - \\ -- & \times & -\end{array}$

\footnotetext{
1 Statospore

2 Chlanydomona-type Ilagellate

Chlarnydomonas-type Ilagellate and coccold form
} 
[ODominant or co-dominant]

\begin{tabular}{|c|c|c|c|c|c|c|c|c|c|}
\hline PHYTOPLANKTON & $8 / 28 / 80$ & $10 / 28 / 80$ & $6 / 25 / 81$ & Zl16/81 & $8 / 03 / 81$ & $8 / 27 / 81$ & $9 / 28 / 81$ & $7 / 21 / 82$ & $8 / 17 / 82$ \\
\hline \multicolumn{10}{|l|}{ Chlorophyta } \\
\hline \multicolumn{10}{|l|}{ Chlorophyceae } \\
\hline Ankistrodesmus falcatus G.M. Smith & -- & (ख) & $\mathrm{x}$ & $\mathrm{x}$ & - & -- & -- & -- & -- \\
\hline \multicolumn{10}{|l|}{ Ankistrodesmus falcatus v. } \\
\hline mirabilis (West \& West) G.S. West & -- & -- & -- & -- & -- & -- & $\mathrm{x}$ & -- & -- \\
\hline Golenkinia paucispina West \& West & -- & -- & -- & -- & -- & -- & -- & -- & $\mathrm{x}$ \\
\hline Kirchneriella lunaris v. Dianae Bohlin & $2--$ & -- & -- & -- & -- & -- & -- & $\mathrm{x}$ & -- \\
\hline Oocystis sp. Naegeli in A. Braun & -- & -- & -- & -- & $\mathrm{x}$ & -- & -- & -- & $\mathrm{x}$ \\
\hline Unidentified & -- & -- & -- & -- & $\mathrm{x}$ & $\mathrm{x}$ & $\mathrm{x}$ & (ख) & $\mathrm{x}$ \\
\hline \multicolumn{10}{|l|}{ Chrysophyta } \\
\hline \multicolumn{10}{|l|}{ Bacillariophyceae } \\
\hline Achnanthes lanceolata (Breb.) Grun. & $\mathrm{x}$ & -- & - & -- & -- & - & -- & -- & - \\
\hline Achnanthes minutissima Kutz. & -- & -- & -- & -- & -- & -- & -- & -- & $\mathrm{x}$ \\
\hline Cyclotella sp. Kutz. & -- & (X) & -- & -- & -- & $x$ & -- & -- & -- \\
\hline Cyclotel1a atomus Hust. & $\mathrm{x}$ & - & -- & -- & - & - & -- & -- & -- \\
\hline Cyclotella pseudostelligera Grun. & -- & -- & -- & -- & -- & -- & -- & -- & (X) \\
\hline Gomphonema sp. Hust. & -- & -- & -- & -- & -- & -- & -- & $\mathrm{x}$ & $\mathrm{x}$ \\
\hline Nitzschia sp. Hassal & -- & -- & -- & -- & -- & -- & -- & $\mathrm{x}$ & -- \\
\hline Nitzschia acicularis w. Sm. & -- & -- & -- & -- & $\mathrm{x}$ & -- & $\mathrm{x}$ & $\mathrm{x}$ & -- \\
\hline Nitzschia palea (Kutz.) w. Sm. & -- & -- & -- & $\mathrm{x}$ & -- & -- & $x$ & $\mathrm{x}$ & -- \\
\hline Synedra sp. Ehrenbers & -- & -- & -- & $\mathrm{x}$ & $\mathrm{x}$ & -- & -- & $x$ & -- \\
\hline Synedra actinastroides Lerm. & -- & -- & -- & -- & -- & -- & -- & $x$ & -- \\
\hline Synedra minuscula Grun. & -- & -- & -- & -- & -- & -- & -- & $\mathrm{x}$ & (Х) \\
\hline Synedra rumpens Kutz. & -- & -- & -- & -- & -- & -- & -- & $x$ & $\mathrm{x}$ \\
\hline Unidentified pennate & -- & -- & -- & $\mathrm{x}$ & -- & -- & -- & $\mathrm{x}$ & $\mathrm{x}$ \\
\hline Unidentified centric & -- & -- & (x) & $x$ & $\mathrm{x}$ & -- & -- & -- & -- \\
\hline \multicolumn{10}{|l|}{ Chrysophyceae } \\
\hline Dinobryon sertularia Ehrenberg & -- & -- & -- & -- & - & -- & -- & -- & $\mathrm{x}$ \\
\hline Chlorochromonas sp. (?) Lewis & -- & -- & -- & (x) & (ख) & (x) & (x) & $x$ & -- \\
\hline (Ochromonas sp. Wystozki) & & & & & & & & & \\
\hline \multicolumn{10}{|l|}{ Cyanophyta } \\
\hline \multicolumn{10}{|l|}{ Cyanophyceae } \\
\hline Anabaena sp. Bory & $\mathrm{x}$ & -- & -- & -- & -- & $\mathrm{x}$ & -- & -- & -- \\
\hline Chroococcus sp. Naegeli & (Х) & -- & -- & -- & -- & -- & -- & -- & -- \\
\hline Lyngbya 1 imnetica Lermermann & $x$ & -- & -- & -- & -- & -- & -- & -- & -- \\
\hline Microcystis sp. Kuetzing & $x$ & $\mathrm{x}$ & -- & -- & -- & -- & -- & -- & -- \\
\hline Oscillatoria sp. Vaucher & $x$ & $\mathrm{x}$ & -- & -- & -- & $\mathrm{x}$ & -- & -- & -- \\
\hline \multicolumn{10}{|l|}{ Rhabdoderma lineare Schmidle \& } \\
\hline Lauterborn in Schmidle & $x$ & -- & $x$ & $x$ & -- & -- & $\mathrm{x}$ & $\mathrm{x}$ & $\mathrm{x}$ \\
\hline \multicolumn{10}{|l|}{ Cryptophyta } \\
\hline Unidentified & $x$ & -- & -- & -- & -- & -- & -- & -- & -- \\
\hline \multicolumn{10}{|l|}{ Euglenophyta } \\
\hline Unidentified & -- & -- & -- & -- & -- & -- & -- & -- & $x$ \\
\hline \multicolumn{10}{|l|}{ Pyrrophyta } \\
\hline \multicolumn{10}{|l|}{ Dinophyceae } \\
\hline Unidentified & -- & -- & -- & -- & -- & -- & -- & -- & $\mathrm{x}$ \\
\hline \multicolumn{10}{|l|}{ Other } \\
\hline Unidentified flagellates & (x) & -- & ( & $\mathrm{x}$ & $\mathrm{x}$ & (x) & (X) & (X) & $\mathrm{x}$ \\
\hline
\end{tabular}


VENUS LAKE

[ODominant or co-dominant]

Chlorophyta

Chlorophyceae

Ankistrodesmus falcatus G.M. Smith

(x) --
--
--
--
--
--
--
--

--
--
--
--
--
--
$x$

x

$\mathrm{X}$

$\begin{array}{lll}\mathrm{x} & -- & \mathrm{x} \\ \mathrm{x} & -- & -- \\ -- & \mathrm{x} & -- \\ -- & -- & 8 \\ -- & -- & \mathrm{x} \\ -- & \mathrm{x} & -- \\ -- & -- & \mathrm{x} \\ \mathrm{x} & -- & \mathrm{x}\end{array}$

Chrysophyta

\section{Bacillariophyceae}

Cyclotella sp. Kutz.

Cyclotella pseudostelligera Grun.

Nitzschia acicularis W. Sm.

Nitzschia fonticola Grun.

Nitzschia palea (Kutz.) W. Sm.

Synedra sp. Ehrenbers

Synedra rumpens Kutz.

Unidentified pennate

Unidentified centric

Chrysophyceae

Dinobryon sertularia Ehrenberb

Dinobryon campanulostipitatum Ahlstrorn

Chlorochromonas sp. Lewis

(Ochromonas sp. Wystozki)

Cyanophyta

Cyanophyceae

Aphanothece sp. Naegeli

Chroococcus dispersus (Keiss1.) Lemm.

Dactylococcopsis sp. (Reinsch) Hans.

Microcystis sp. Kuetzing

Oscillatoria sp. Vaucher

Rhabdoderma lineare Schmidle \& Lauterborn in Schmidle

Euglenophyta

Euglenophyceae

Trachelomonas sp. Ehrenberg other

Unidentified flagellates

Fungi imperfecti

Phycomycetes 
[ODominant ox co-dominant]

PHYTOPLANKTON

Chlorophyta

Chlorophyceae

Ankistrodesmus falcatus G.M. Smith

Characium sp. A. Braun in Kuetzing

Eudorina elegans Ehrenberg

Gloeocystis sp. Naegeli

Quadrigula closterioides (Bohlin) in Printz

Tetraedron minimum (A. Braun) Hansgirg

Chrysophyta

Bacillariophyceae

Achnanthes sp. Bory

Achnanthes microcephala (Kutz.) Grun.

Asterionella formosa Hasall

Cyclotella sp. Kutz.

Eunotia perpusilla Grun.

Melosira distans (Ehr.) Kutz.

Synedra delicatissima $W$. Sm.

Chrysophyceae

Dinobryon bavaricum Imhof

Cyanophyta

Cyanophyceae

Anabaena affinis Lemmermann

Chroococcus sp. Naegeli

Chroococcus dispersus var. minor G.M. Smith

Microcystis sp. Kuetzing

Microcystis aeruginosa (Kuetz) Elenkin

Oscillatoria sp. Vaucher

Rhabdoderma lineare Schm./Laut. in Schmidle

Cryptophyta

Cryptophyceae

Cryptomonas sp. Ehrenberg

Unidentified

Euglenophyta

Euglenophyceae

Trachelomonas sp. Ehrenberg

Pyrrophyta

Dinophyceae

Glenodinium sp. Stein

Other

Unidentified flagellates

$\begin{array}{lll}-- & -- & x \\ -- & x & -- \\ -- & -- & x \\ -- & \times & -- \\ -- & x & -- \\ -- & x & x\end{array}$

-- $\quad$-- $\quad x$

-- $\quad x \quad-$

$x$ X (X)

-- $\quad x$

(ख)

- $\quad x \quad-$

-- $x$ (X)$$
\text { (1) }
$$

$-$

-

$-$

$\begin{array}{lll}-- & - & x \\ -- & - & x \\ -- & 8 & x\end{array}$


APPENDIX B.--Taxonomic identification of zooplankton in eight study lakes in the Mount St. Helens area, Washington

COLDWATER LAKE

[ODominant or co-dominant]

\begin{tabular}{|c|c|c|c|c|c|c|c|c|c|}
\hline ZOOPLANKTON & $6 / 17 / 81$ & $7 / 16 / 81$ & $8 / 5 / 81$ & $8 / 27 / 81$ & $9 / 29 / 81$ & $5 / 25 / 82$ & $6 / 24 / 82$ & $7 / 20 / 82$ & $8 / 17 / 82$ \\
\hline \multicolumn{10}{|l|}{ Arthropoda } \\
\hline \multicolumn{10}{|l|}{ Crustacea } \\
\hline \multicolumn{10}{|l|}{ Cladocera } \\
\hline Ceriodaphnia sp. Dana & - & - & - & - & - & $\mathrm{x}$ & - & - & - \\
\hline Ceriodaphnia quadrangula (Mu11.) & - & - & - & (x) & (x) & - & - & - & - \\
\hline Ceriodaphnia reticulata (Jurine) & - & - & - & - & $\mathrm{x}$ & - & - & - & - \\
\hline Daphnia sp. (O.F. Muller) & - & - & - & $\mathrm{x}$ & - & - & - & - & - \\
\hline Daphnia laevis Birge & - & - & - & - & $\mathrm{x}$ & - & - & - & - \\
\hline Daphnia middendorffiana Fischer & - & - & - & - & $x$ & - & - & - & - \\
\hline Daphnia pulex Leydig & - & - & - & - & - & (8) & (x) & (X) & (x) \\
\hline \multicolumn{10}{|l|}{ Copepoda } \\
\hline \multicolumn{10}{|l|}{ Cyclopoida } \\
\hline Cyclops vernalis Fischer & $x$ & $\mathrm{x}$ & $\mathrm{x}$ & $\mathrm{x}$ & - & - & - & - & - \\
\hline Cyclops bicuspidatus thomasi Forbes & - & - & - & - & - & - & $\mathrm{x}$ & - & - \\
\hline Unidentified & (x) & $\mathrm{x}$ & (x) & $x$ & - & $\mathrm{x}$ & - & - & $\mathrm{x}$ \\
\hline Nauplii & $\mathrm{x}$ & $\mathrm{x}$ & $\mathrm{x}$ & - & - & - & - & - & $\mathrm{x}$ \\
\hline
\end{tabular}

Rotifera

Monogononta

Ploima

Kellicottia longispina (Kellicott)

Keratella hiemalis Carlin

Keratella quadrata (O.F. Muller)

Flosculariaceae

Filinia longiseta Ehrenbers Other

Vorticella sp. Linn. 


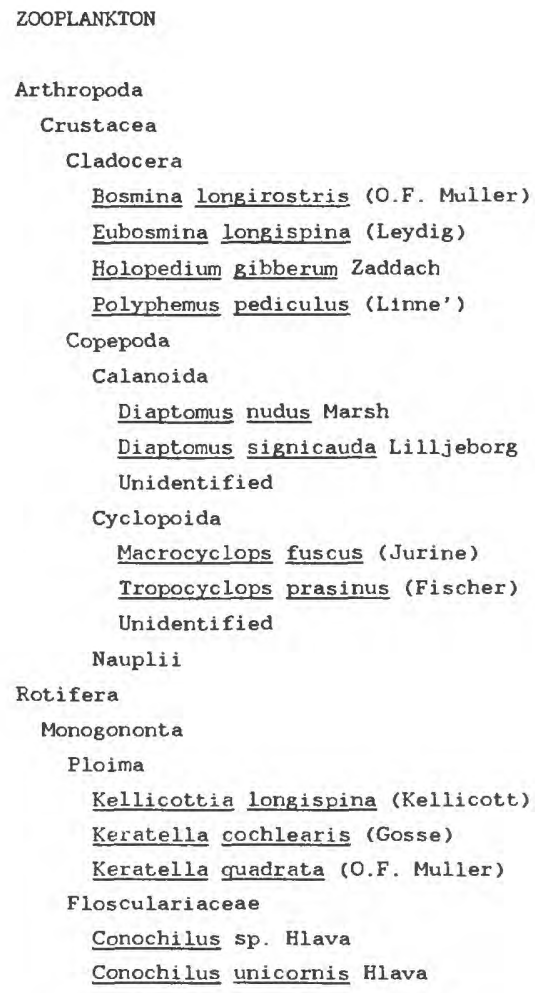

FAWN LAKE

[ O Dominant or co-dominant]

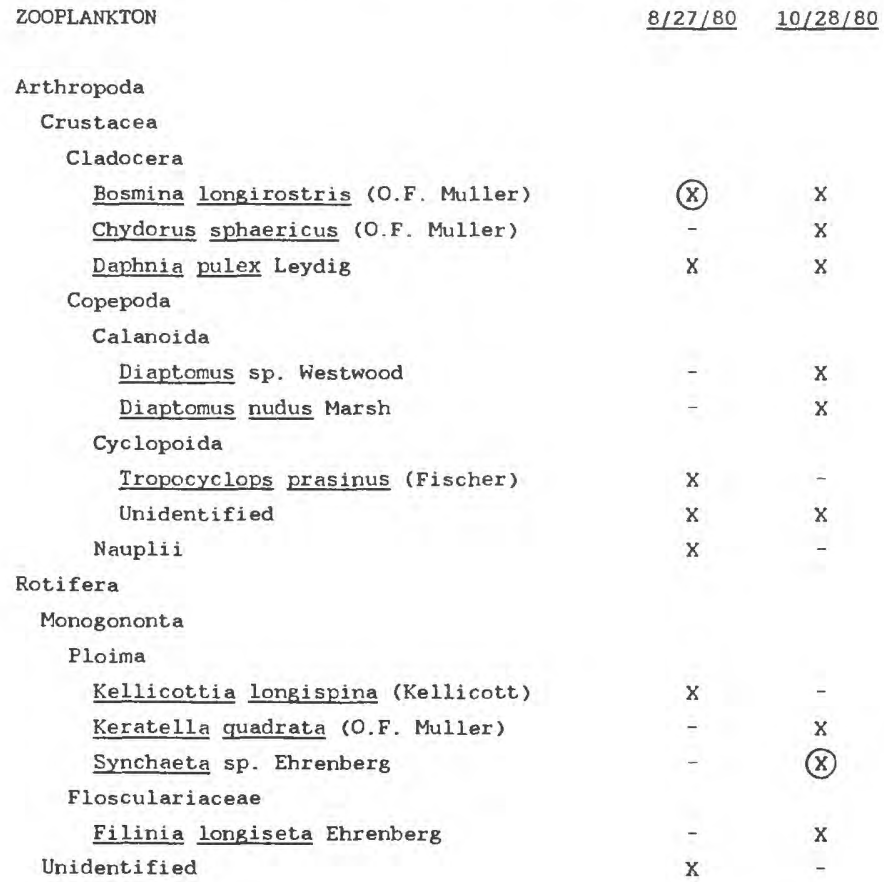


CASTLE

[ $O$ Dominant or co-dominant]

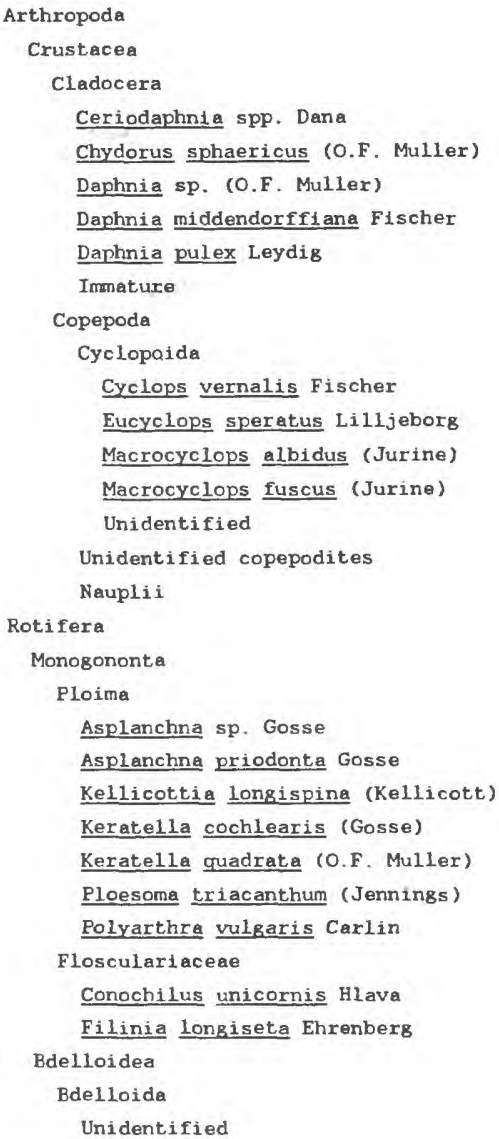


SPIRIT LAKE

[ $\bigcirc$ Dominant or co-dominant]

ZOOPLANKTON

$\underline{10 / 16 / 80}^{\circ} \quad 5 / 12 / 81$ I/16/81 $8 / 3 / 8$

$8 / 28 / 81$

$9 / 28 / 81$

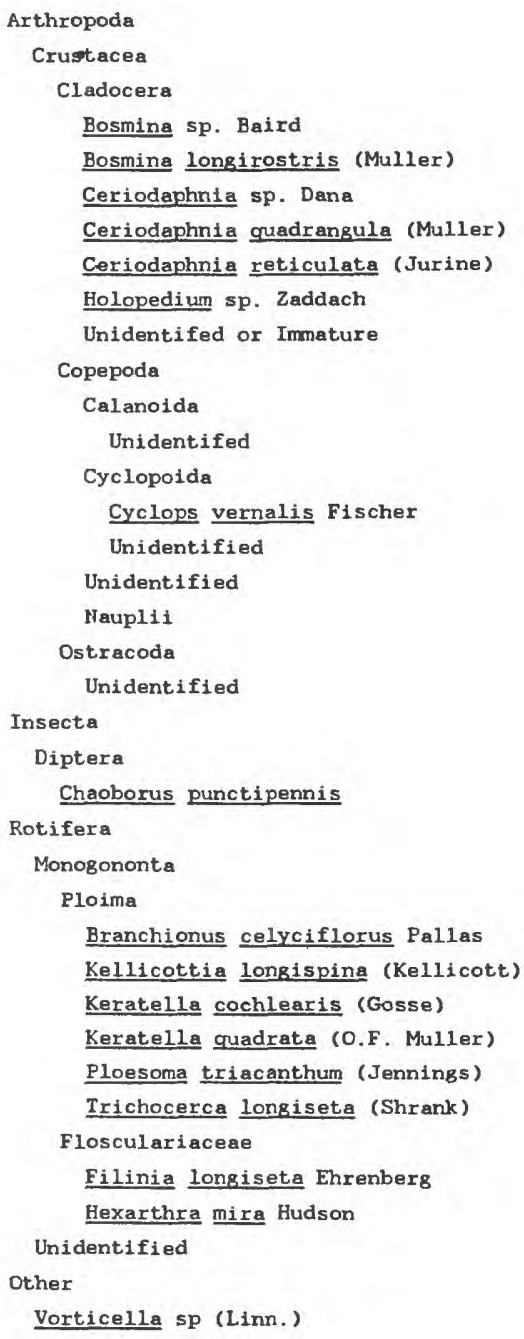

(

(ब)

Organisms in sample may possibly be artifacts 
[O Dominant or co-dominant]

\begin{tabular}{|c|c|c|c|c|c|c|c|c|c|}
\hline ZOOPLANKTON & $\underline{8 / 28 / 80^{\mathrm{a}}}$ & $10 / 28 / 80$ & $6 / 25 / 81$ & $\underline{7 / 16 / 81}$ & $8 / 3 / 81$ & $8 / 27 / 81$ & $9 / 28 / 81$ & $7 / 21 / 82$ & $8 / 17 / 82$ \\
\hline \multicolumn{10}{|l|}{ Arthropoda } \\
\hline \multicolumn{10}{|l|}{ Crustacea } \\
\hline \multicolumn{10}{|l|}{ Cladocera } \\
\hline Bosmina longirostris (O.F. Muller) & $\mathrm{x}$ & $\mathrm{x}$ & - & - & $\mathrm{x}$ & - & - & - & - \\
\hline Ceriodaphnia guadrangula (Muller) & $\mathrm{x}$ & $\mathrm{x}$ & - & - & - & - & - & - & - \\
\hline Ceriodaphnia reticulata (Jurine) & - & - & - & - & - & - & $\mathrm{x}$ & $\mathrm{x}$ & - \\
\hline Daphnia middendorffiana Fischer & - & - & - & - & (x) & - & - & - & - \\
\hline Daphnia pulex Leydis & - & (X) & - & - & - & - & $\mathrm{x}$ & - & - \\
\hline Holopediun gibberum Zaddach & - & - & - & - & - & - & $\mathrm{x}$ & - & - \\
\hline Unidentified & - & - & - & - & $\mathrm{x}$ & - & - & - & - \\
\hline \multicolumn{10}{|l|}{ Copepoda } \\
\hline \multicolumn{10}{|l|}{ Cyclopoida } \\
\hline Cyclops vernalis Fischer & - & $\mathrm{x}$ & - & - & $\mathrm{x}$ & $\mathrm{x}$ & $\mathrm{x}$ & - & $x$ \\
\hline Eucyclops agilis (Koch) & - & - & - & - & - & - & - & - & $x$ \\
\hline Eucyclops prionophorus Kiefer & - & - & $\mathrm{x}$ & - & - & - & - & - & - \\
\hline Macrocyclops ater (Herrick) & - & $\mathrm{x}$ & - & - & - & - & - & - & - \\
\hline Paracyclops poppei (Rehberg) & - & - & - & $\mathrm{x}$ & - & - & - & - & - \\
\hline Unidentified & - & - & (X) & $\mathrm{x}$ & $\mathrm{x}$ & $\mathrm{x}$ & (X) & (X) & (X) \\
\hline Nauplii & - & - & $\mathrm{x}$ & $\mathrm{x}$ & $\mathrm{x}$ & (8) & $\mathrm{x}$ & $\mathrm{x}$ & $x$ \\
\hline \multicolumn{10}{|l|}{ Rotifera } \\
\hline \multicolumn{10}{|l|}{ Monogononta } \\
\hline \multicolumn{10}{|l|}{ Ploima } \\
\hline Kellicottie Longispina (Kellicott) & - & - & $\mathrm{x}$ & (X) & $\mathrm{x}$ & $\mathrm{x}$ & - & $\mathrm{x}$ & - \\
\hline Keratella quadrata (O.F. Muller) & - & - & - & - & - & - & - & (X) & (X) \\
\hline Lepade1la ovalis (O.F. Muller) & - & - & - & $x$ & - & - & - & - & - \\
\hline \multicolumn{10}{|l|}{ Flosculariaceae } \\
\hline Filinia Longiseta Ehrenberg & - & - & - & - & $\mathrm{x}$ & - & - & - & - \\
\hline \multicolumn{10}{|l|}{ Other } \\
\hline Vorticella sp (Linn.) & - & - & - & - & - & $\mathrm{x}$ & - & - & - \\
\hline \multicolumn{10}{|c|}{ Organisms in sample may possibly be artifacts. } \\
\hline \multicolumn{10}{|c|}{ VENUS LAKE } \\
\hline \multicolumn{10}{|c|}{ [ O Dominant or co-dominant] } \\
\hline ZOOPLANKTON & $10 / 16 / 80$ & $6 / 25 / 81$ & $7 / 15 / 81$ & $8 / 4 / 81$ & $8 / 26 / 81$ & $9 / 29 / 81$ & $7 ; 20 / 82$ & $8 / 19 / 82$ & \\
\hline
\end{tabular}

Arthropoda
Crustacea

Cladocer

Ceriodaphnia quadrengula (Muller)

Daphnia sp. (O.F. Muller)

Holopedium gibberum Zaddach

Immature

Copepoda

Calanoida

Diaptomus sp. Westwood

Diaptomus nevadensis Light

Cyclopoida

Cyclops vernalis Fischer

Orthocyclops modestus (Herrick)

Unidentified

Nauplii

$10 / 16 / 80 \quad 6 / 25 / 81 \quad 7 / 15 / 81 \quad 8 / 4 / 81 \quad 8 / 26 / 81 \quad 9 / 29 / 81 \quad 7 / 20 / 82 \quad 8 / 19 / 82$

Rotifera

Monogononte

Ploima

Branchionus calyciflorus Pallas

Kellicottia Longispina (Kellicott)

Keratella cochlearis (Gosse)

Keratella quadrata (O.F. Muller)

Keratella testudo (Ehren) Carlin

Flosculariaceae

Conochilus unicurnis Hlava

Filinia Longiseta Ehrenberg

Unidentified 
WALUPT LAKE

[ $O$ Dominant or co-dominant]

ZOOPLANKTON

$\underline{6 / 23 / 80} \quad \underline{8 / 11 / 80} \quad \underline{10 / 6 / 80}$

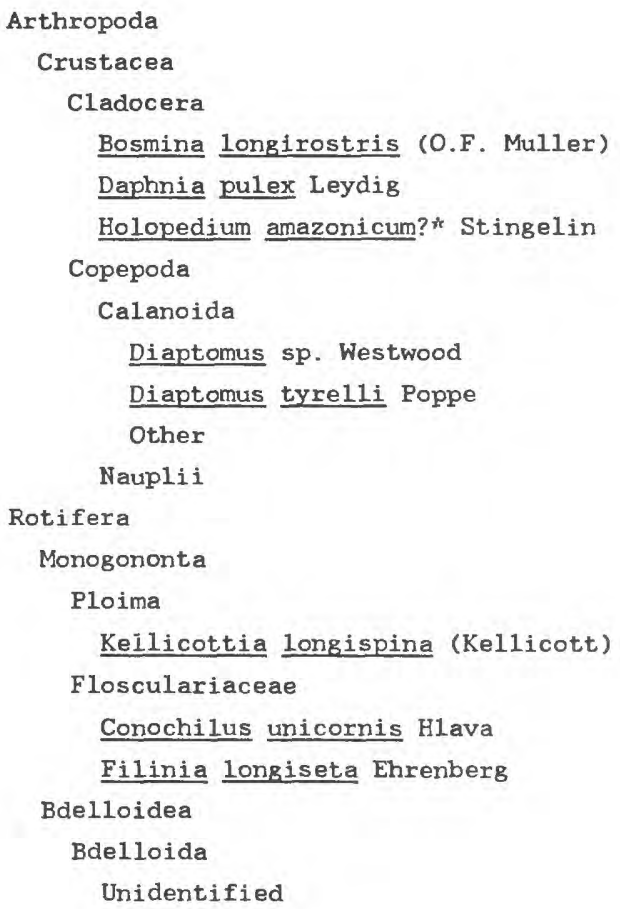

$$
x
$$

x

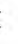

* $\underline{H}$. amazonicum is reported from Louisiana and other localities in southeastern United States; This is more likely $\underline{\text { H. gibberum which is }}$ common in northern United States (Ward and Whipple, 1959, p. 603-604). 